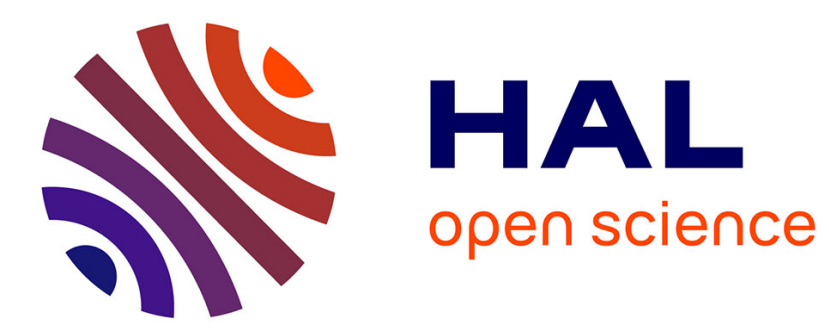

\title{
Bank Liquidity Management and Bank Capital Shocks
}

Robert Deyoung, Isabelle Distinguin, Amine Tarazi

\section{To cite this version:}

Robert Deyoung, Isabelle Distinguin, Amine Tarazi. Bank Liquidity Management and Bank Capital Shocks. 2017. hal-01559053

\section{HAL Id: hal-01559053 \\ https://hal-unilim.archives-ouvertes.fr/hal-01559053}

Preprint submitted on 10 Jul 2017

HAL is a multi-disciplinary open access archive for the deposit and dissemination of scientific research documents, whether they are published or not. The documents may come from teaching and research institutions in France or abroad, or from public or private research centers.
L'archive ouverte pluridisciplinaire HAL, est destinée au dépôt et à la diffusion de documents scientifiques de niveau recherche, publiés ou non, émanant des établissements d'enseignement et de recherche français ou étrangers, des laboratoires publics ou privés. 


\title{
Bank Liquidity Management and Bank Capital Shocks
}

\author{
Robert DeYoung* \\ Kansas University, School of Business \\ 1654 Naismith Avenue, Lawrence, KS 66045 USA \\ Isabelle Distinguin \\ Université de Limoges, LAPE \\ 5 rue Félix Éboué, BP 3127 \\ 87031 Limoges Cedex 1 FRANCE \\ Amine Tarazi \\ Université de Limoges, LAPE \\ 5 rue Félix Éboué, BP 3127 \\ 87031 Limoges Cedex 1 FRANCE
}

June 15, 2017

\begin{abstract}
The Basel III Accord imposes minimum liquidity standards on bank balance sheets that are already constrained by minimum capital standards. It is not clear whether or how banks' behaviors will change in this new joint-constraint regime. To gain some insight, we study the balance sheet liquidity behavior of U.S. banking companies in response to negative equity capital shocks prior to the implementation of Basel III. Our 1998-2012 data indicate that banks treated regulatory capital and balance sheet liquidity (e.g., net stable funding ratios, core deposits-to-loans, liquid assets-to-assets) as substitutes rather than complements. This main finding is limited to so-called 'community banks' with assets less than $\$ 1$ billion; equity capital and liquidity were neither substitutes nor complements at larger banks. In the course of rebuilding their capital ratios, shocked community banks substituted away from loans and loan commitments and reduced their dividend payouts, actions that resulted in greater balance sheet liquidity. Thus, in the state of nature that has traditionally most concerned bank regulators (i.e., stress to bank equity capital), community banks increase their liquidity buffers. Given that these lenders do not pose systemic risk, and that they have historically exceeded the Basel III liquidity minimums by wide margins, our findings suggest that imposing minimum liquidity thresholds on small banks will likely yield little prudential benefit.
\end{abstract}

Key words: Bank capital, bank liquidity, Basel III, lending, net stable funding ratio

JEL codes: G21, G28

*Corresponding author: Kansas University School of Business, Capitol Federal Hall, 1654 Naismith Avenue, Lawrence, KS 66045 USA, rdeyoung@ku.edu, 785-864-1806. The authors thank Allen Berger, Christa Bouwman, Charles Calomiris, Shane Johnson, Benjamin Munyan, Matthew Plosser and Joao Santos for helpful comments and suggestions. The authors jointly thank the Manhattan Institute for research support, and DeYoung thanks the Capitol Federal Foundation for research support. 


\section{Introduction}

In response to the stresses experienced by banks and short-term credit markets during the global financial crisis, the Basel III Accord (2010-2011) introduced minimum liquidity rules for banks in its signatory nations. These new regulatory standards-the Liquidity Coverage Ratio (LCR) and the Net Stable Funding Ratio (NSFR)—impose potentially binding liquidity constraints on banks that are already constrained by minimum equity capital thresholds. Banks in most countries are expected to come gradually into compliance with the new liquidity minimums between 2015 and 2019 .

The liquidity of banks' assets, the stability of banks' liabilities, and banks' desired levels of equity capital are interrelated in ways that are not fully understood by regulators and researchers. ${ }^{1}$ For example, consider the impact of a negative capital shock on a bank's liquidity position. On the one hand, if the reduction in equity capital causes uncertainty for (uninsured) bank creditors, the bank might treat capital and liquidity as substitutes. To prepare for potential creditor runs under such a scenario, a bank could increase the liquidity of its assets (e.g., shift from illiquid loans to liquid securities) and/or increase the duration of its liabilities (e.g., shift to core deposits). On the other hand, if the reduction in equity capital reduces franchise value and hence makes banks less risk averse, the bank might treat capital and liquidity as complements. Under this scenario, a bank might increase its credit risk, interest rate risk, and/or liquidity risk, with the latter manifested in decreased asset liquidity (e.g., shift from safe, liquid securities to risky, illiquid loans) and/or decreased liability duration (e.g., shift expensive but stable longterm time deposits to less expensive but less stable short-term brokered deposits or commercial paper). Given that we have an imperfect understanding of how banks manage these relationships under the regulatory status quo of a single equity capital constraint, adding a liquidity constraint to the regulatory mix is unlikely to clarify matters.

Banking theory has from the beginning recognized that bank assets and bank liabilities are jointly related in the production of financial services and the generation of both credit risk and liquidity risk (e.g.,

\footnotetext{
${ }^{1}$ For example, many if not most banking industry experts were taken by surprise when the liquidity risk embedded in the balance sheets of large banks ignited the financial crisis.
} 
Klein 1971, Monti 1972, Bryant 1980, Diamond and Dybig 1983). Perhaps ironically, in much of the ensuing theoretical and empirical banking literatures, the topics of bank credit risk and bank illiquidity risk have been pursued separately. In reaction to the global financial crisis, in which liquidity risk and credit risk were joint determinants of failure at many large banking companies, researchers are increasingly investigating bank insolvency and illiquidity as interrelated phenomena. Informing and testing the efficacy of joint regulatory constraints like those imposed by Basel III is a prime motivation.

Perhaps the most relevant example in the emerging theory literature is Walther (2016), who shows how insolvency risk and liquidity risk can be efficiently internalized by imposing joint constraints on equity ratios and liquidity positions- that is, an approach consistent in spirit with that prescribed by Basel III. Other models link liquidity regulation to capital market incentives. Calomiris, Heider and Hoerova (2013) emphasize the role of cash holdings: Holding more cash reduces the chances that creditor runs will make a bank illiquid, while at the same time displacing investment in riskier assets. Thus, by stabilizing the banking franchise, stricter liquidity regulations should incentivize banks to hold additional equity capital to protect that franchise. Acharya, Mehran and Thakor (2010) propose a regulatory regime in which a portion of bank equity capital (a) is pledged to financing low-risk liquid assets and (b) gets claimed by the regulator should the bank approach insolvency. The former condition reduces bank liquidity risk, while the latter condition reduces default risk by strengthening the incentives of junior creditors to monitor the bank.

The emerging empirical literature on the interrelations of bank capital and bank liquidity thus far reached few firm conclusions. Imbierowicz and Rauch (2014) find that although both credit risk and liquidity risk increase bank failure risk, when experienced jointly these two types of risk can either amplify or offset each other. Both Schmaltz, et al (2014) and Birn, Dietsch and Durant (2015) simulate the likely response of banks to Basel III's four joint constraints (risk-based capital, leverage capital, NFSR, and LCR) but find starkly different results: The former study concludes that banks will manage their liquidity positions under joint constraints by increasing their stable deposit funding rather than increasing their liquid assets investments; the latter study concludes just the opposite. Adding to the noise, 
Distinguin, Roulet, and Tarazi (2013) find that regulatory capital ratios for a large international sample of banks tend to decrease as banks become more illiquid (capital and liquidity are complements), but find an increasing relationship between regulatory capital ratios and illiquidity for a sample of small U.S. banks (capital and liquidity are substitutes). ${ }^{2}$

Clearly, testing how joint equity and liquidity constraints affect bank balance sheet management poses empirical challenges. This is especially true in the U.S., where the Federal Reserve did not propose its NSFR rule until May 2016 and hence banks have not yet faced the joint constraints set forth in Basel III. ${ }^{3}$ In this paper, we study the interrelationships between bank liquidity and bank capital at U.S. banks in a pre-Basel III world, when regulation constrained banks' equity capital decisions but did not constrain banks' liquidity positions. We design an empirical strategy that uses bank financial data from this singleconstraint environment to infer how banks are likely to manage their capital and liquidity positions under the coming joint-constraint environment. Specifically, we investigate whether and how U.S. bank holding companies adjusted their liquidity positions in response to negative shocks to their capital ratios between 1998 and 2012. For the remainder of this paper, we use the terms bank, banking company, and bank holding company interchangeably.

In the first stage of our investigation, we use standard partial adjustment techniques to estimate an internal capital ratio target for each bank in every year of our data. We then define a negative capital ratio shock as follows: If a bank is already operating below its own internal capital ratio target, and then it experiences an additional reduction in its capital ratio that moves it even further below its internal target, we assume that this reduction in capital was involuntary and thus constitutes an exogenous shock. In the second stage of our investigation, we estimate how banks' liquidity ratios—net stable funding ratios, core deposit ratios, liquid asset ratios—-responded to those negative capital shocks. Our focus throughout the paper is on bank liquidity positions (an operating risk and prudential regulation concept) and not on bank

\footnotetext{
${ }^{2}$ For a more complete review of the literature on the interaction of bank capital and liquidity regulations, see Basel Committee on Banking Supervision (2016).

${ }^{3}$ For details, see https://www.federalreserve.gov/newsevents/press/bcreg/20160503a.htm.
} 
liquidity creation (a bank production concept). ${ }^{4}$ Finally, we attempt to identify the channels through which capital shocks are transmitted into changes in liquidity positions, and the implications of those channels for bank regulation and the macro-economy.

Our tests reveal robust circumstances under which banks treat equity capital ratios and liquidity ratios as effective substitutes. We find that banks adjust their liquidity ratios upward in response to negative shocks to their risk-weighted regulatory capital ratios, but we find no similar evidence following negative shocks to their accounting capital (leverage) ratios. This suggests that U.S. banks have historically treated capital and liquidity as substitutes, due at least in part to the presence of potentially binding risk-weighted regulatory capital minimums. Thus, we find evidence of an unexpected prudential synergy that emanates from establishing minimum regulatory capital standards: In the course of repairing their regulatory capital ratios, capital-constrained banks take actions that enhance their liquidity risk positions, even in the absence of formal regulatory liquidity minimums.

These results are heavily concentrated among so-called 'community banks' with assets less than $\$ 1$ billion, which comprise approximately three-quarters of the annual observations in our data set. We identify five qualitatively different adjustments made by capital-shocked community banks to repair their regulatory capital ratios: They slow their asset growth rates, reduce the percentage of assets invested in loans, reduce the percentage of assets invested in loans with high capital risk weights, reduce their commitments to making future loans, and reduce their dividend payout ratios. Each of these actions contributes to upward adjustments to risk-based capital ratios; the latter four actions also result in increased bank liquidity positions. Thus, regulatory-driven pressures to improve capital ratios result in

\footnotetext{
${ }^{4}$ See Bouwman (2015) for a thorough review of bank liquidity creation. While bank liquidity and bank liquidity creation are closely related, they are not identical concepts in either measurement or in purpose. During our 19982012 pre-Basel III-implementation sample period, the typical U.S. banking company assessed its liquidity position using simple balance sheet ratios such as cash-to-assets, liquid assets-to-total assets, or loans-to-core deposits. In today's Basel III world, many U.S. banking companies and most non-U.S. banking companies additionally assess their liquidity positions using the NSFR and LCR measures, because regulators require them to do so. In contrast, banking companies have no operational, risk-management, or regulatory compliance reason to calculate the amount of liquidity that they create. While the Berger and Bouwman (2009) liquidity creation measure is a conceptual and applied advance in measuring what banking companies produce, it remains an academic concept and has thus far has played no explicit role in the regulation of liquidity risk or the liquidity risk-taking of banks, which are the focus of this study.
} 
positive prudential synergies from increased liquidity, but the adjustments through which these synergies are generated levy macro-economic costs in the form of reduced credit supply.

Our results provide strong evidence that small U.S. bank holding companies have historically self-managed their liquidity positions in a manner consistent with both the post-crisis concerns of bank regulators and the spirit of the new Basel III liquidity regulations. These small banking companies pose little if any systemic risk to the U.S. economy. Moreover, even apart from the liquidity-enhancing responses to capital shocks documented here, these smaller banks tend to operate with substantially higher stores of liquidity than larger commercial banking companies (see Figure 1). Thus, our findings lend support for U.S. regulatory policies that (unlike in Europe) exclude most smaller banks from having to comply with the new Basel III liquidity rules. In practice, imposing NSFR and LCR constraints on small banking companies is likely to be redundant and hence unnecessarily costly. In contrast, we find no evidence of any similar linkage between capital shocks and liquidity management at larger banks. Thus, effective regulatory efforts to mitigate liquidity risk at non-community banks likely requires a separate liquidity regulation, one example being the combination of separate liquidity and capital constraints in Basel III.

The remainder of the paper is organized as follows: In section 2 we develop the two-stage empirical methodology described briefly above, with an emphasis on our identification of exogenous changes in bank equity capital ratios. In section 3 we describe our data sources, define the variables used to specify our two-stage model, and layout our estimation plan. In section 4 we present and discuss the results of our estimations. In section 5 we briefly summarize our findings and consider the implications of our results for regulatory policy.

\section{Methodology}

Our main objective is to test whether and how capital-regulated banks adjust their liquidity positions in response to negative equity capital shocks, in the absence of explicit regulatory liquidity rules. This objective imposes two features on our test methodology: First, we need to estimate our models for 
banking data that was generated prior to the implementation of the Basel III liquidity rules. This is easily satisfied by using annual financial data on U.S. bank holding companies (the publicly available Federal Reserve Y9-C database) between 1998 and 2012. Table 1 displays descriptive statistics and definitions for all of the variables in our main data set, which contains 10,807 bank-year observations. These data and variables will be discussed in greater detail below.

Second, within these data, we must identify negative changes in bank equity capital that are plausibly exogenous. This is a thornier problem, especially in the absence of a natural experiment in which capital exogenously becomes deficient at some but not all banks (allowing a difference-indifferences test) or sudden and exogenous bank-specific reductions in capital that occur at different times (allowing an event study test). Our solution to this problem is a key part of our methodology and represents a potential contribution to the literature. Using established estimation techniques (Berger, et al 2008; Flannery and Rangan 2008; DeYoung and Jang 2016), we calculate internal equity capital ratio targets for every bank in each year of the data. We then assume that an exogenous negative shock to bank equity capital has occurred when we observe the following pattern in the data: A bank that is operating below its own internal equity capital ratio target—and thus has a clear incentive to increase this ratioexperiences instead a reduction in its equity capital ratio that moves the bank even further below its internal target.

2.1. Estimating capital targets. We use a partial adjustment model to estimate banks' internal capital ratio targets in each year of our 1998-2012 data. We begin by assuming that each bank has a target capital ratio that can be expressed as a function of observable characteristics:

$$
K_{i, t}^{*}=\beta \cdot X_{i, t-1}
$$

where $K_{i, t} *$ is the bank $i$ 's target capital ratio at time $t, X_{i, t-1}$ is a vector of observable bank characteristics that determine its target capital ratio, and $\beta$ is a vector of coefficients to be estimated. While equation (1) represents a desired equilibrium, unexpected events can push banks away from $K^{*}$, and returning to the 
desired equilibrium requires banks to make costly adjustments. To capture the adjustment process, we assume that banks close a constant proportion $\lambda$ of the gap between actual $K$ and desired $K^{*}$ each period as follows:

$$
K_{i, t}-K_{i, t-1}=\lambda \cdot\left(K_{i, t} *-K_{i, t-1}\right)+v_{i, t}
$$

where $\lambda$ is the scalar adjustment speed and $v_{i, t}$ is a symmetric random error term. A value of $0<\lambda<1$ indicates a 'partial adjustment' toward the target $K^{*}$ between $t-1$ and $t$. Substituting (1) into (2) and rearranging yields an estimable model:

$$
K_{i, t}=\lambda \beta \cdot X_{i, t-1}+(1-\lambda) \cdot K_{i, t-1}+v_{i, t}
$$

We can recover $\widehat{\lambda}$ directly from the estimated parameter $(\widehat{1-\lambda})$, after which we can then recover $\beta$ by dividing the estimated parameter $\widehat{\lambda \beta}$ by $\hat{\lambda}$. With $\hat{\beta}$ in-hand, we use (1) to calculate a target ratio $K_{i, t}{ }^{*}$ for each bank $i$ in each time period $t$.

While estimation of (3) yields bank- and time-varying values for the target ratios $K_{i, t}{ }^{*}$, the estimated adjustment speed $\widehat{\lambda}$ is a constant. More realistically, banks have unique capital adjustment processes that vary with their own characteristics as well as with external conditions. We express $\lambda$ more flexibly as follows:

$$
\lambda_{i, t}=1 \mathrm{Z}_{i, t-1}
$$

where $\lambda_{i, t}$ is the bank-specific, time-varying speed of adjustment, $Z_{i, t-1}$ is a vector of bank and time period characteristics that affect the adjustment speeds, and $\Lambda$ is a vector of coefficients to be estimated. We can now re-specify the partial capital adjustment model (2) as follows: 


$$
K_{i, t}-K_{i, t-1}=\Lambda \cdot Z_{i, t-1}\left(K_{i, t} *-K_{i, t-1}\right)+v_{i, t}
$$

where the $K_{i, t} *$ are the capital ratio targets from the first-stage. Rewriting $K_{i, t}-K_{i, t-1}$ as $\Delta K_{i, t}$, rewriting $K_{i, t} *-K_{i, t-1}$ as $G A P_{i, t}$, and rearranging yields:

$$
\Delta K_{i, t}=\Lambda \cdot Z_{i, t-1} G A P_{i, t}+v_{i, t}
$$

an estimable equation in which $\Lambda$ is the vector of coefficients to be estimated. With the estimated values $\hat{\Lambda}$ in-hand, we use (4) to calculate an adjustment speed $\lambda_{i, t}$ for each bank $i$ in each time period $t$. The vector of coefficients $\beta$ can now be re-estimated more accurately in the presence of the flexible adjustment speeds. We re-specify the partial adjustment model (3) once again and rearrange as follows:

$$
K_{i, t}-K_{i, t-1}\left(1-\widehat{\lambda_{l, t}}\right)=\beta \cdot \widehat{\lambda_{l, t}} X_{i, t-1}+v_{i, t}
$$

where $\beta$ is a vector of coefficients to be estimated. With these new estimates of $\beta$ in-hand, we use (1) to re-calculate the target ratios $K_{i, t} *$.

Because equation (3) contains a lagged dependent variable, we estimate it using dynamic generalized method of moments (Blundell and Bond 1998) estimation techniques. ${ }^{5}$ Flannery and Hankins (2013) provide further details on the econometrics of models using both lagged dependent variables and fixed effects, applied to problems in corporate finance. We estimate equations (6) and (7) using ordinary least squares. We specify all three estimations with bank and time fixed effects.

2.2. Observing shocks to bank capital. A reduction in a bank's equity capital ratio is typically not an exogenous event. Equity capital can change for three reasons. First, consider a bank with an

\footnotetext{
${ }^{5}$ We use the 'xtdpdsys' procedure in Stata, which first differences the equation and then uses lagged dependent variable levels to instrument for the first difference of the lag. We assume that the explanatory variables are predetermined (not exogenous) and we limit the instrumental variable lags to two periods.
} 
equity capital ratio that differs from its desired equity capital ratio. In response, an above-target bank might take action to increase its financial leverage (e.g., issue additional debt, pay out a special dividend, repurchase shares), while a below-target bank might take action to decrease its financial leverage (e.g., retire debt, issue new shares, shrink the bank), until the capital ratio approaches close to its internal target. These adjustments to bank capital are clearly not exogenous events. Second, the government might pass a new law that increases or decreases the minimum regulatory capital threshold. In response, banks that find themselves out-of-compliance (or far in excess of compliance) with the new threshold will increase (or decrease) both their internal targets as well as their actual capital. While changes in regulatory capital standards are exogenously imposed on banks, neither the announcement nor the implementation are sudden changes, and as such it is problematic to use these events as exogenous shocks in statistical models. ${ }^{6}$ Third, bank equity capital changes with fluctuations in bank earnings, increasing with (undistributed) net income and decreasing with negative net income. The causal source of earnings movements may or may not be exogenous to the bank. On the one hand, net income changes in response to myriad business decisions made by the bank itself in the recent or not-so-recent past; on the other hand, net income also changes in response to plausibly exogenous events that reduce bank earnings (e.g., local economic events, legal judgments and regulatory fines, fraudulent or rogue actions by employees). Unfortunately, the exogenous and non-exogenous drivers of a bank's income and capital are difficult to observe, because they occur simultaneously and hence are pooled in the data.

We use the following logic to find plausibly exogenous bank-level capital shocks: We identify bank-year observations for which a bank is already operating below its internal equity capital ratio target—and hence would like to increase its capital ratio—-but instead experiences an equity capital ratio decrease that causes it to fall further below its internal target. Formally, we define a negative capital shock as a decrease in the actual equity capital ratio $\left(\Delta K_{i, t-1}<0\right)$ at a bank that is already operating below

\footnotetext{
${ }^{6}$ There are exceptions to this. For example, in Great Britain the Financial Services Authority (FSA) can and does assign time-varying, bank-specific minimum capital requirements; an administrative change to a bank's assigned capital minimum could be a surprise to the bank and hence be considered exogenous. See Aiyar, Calomiris and Wieladek (2014).
} 
its internal target capital ratio $\left(G A P_{i, t-2}=K_{i, t-2} *-K_{i, t-2}>0\right)$ that leads to an even larger deviation from its internal target $\left(G A P_{i, t-1}>G A P_{i, t-2}\right)$ :

$$
\begin{aligned}
\operatorname{SHOCK}_{i, t-1} & =1 \text { if } K_{i, t-2}<K_{i, t-2} * \text { and } \Delta K_{i, t-1}<0 \text { and } \triangle G A P_{i, t-1}>0 \\
& =0 \text { otherwise }
\end{aligned}
$$

Because our ultimate goal is to test whether banks alter their liquidity positions at time $t$ in reaction to negative capital shocks in the prior period, (8) defines negative capital shocks as occurring at $t-1$. The $\triangle G A P_{i, t-1}>0$ condition ensures that the reduction in bank capital at $t-1$ is not simply a response to a reduction in the bank's internal capital target: The decline in capital $\Delta K_{i, t-l}$ must be larger than any decline in the capital target $\Delta K_{i, t-1} *$.

Our logic is consistent with previous empirical findings on bank capital management. Berger, et al (2008) show that banks operating well above minimum regulatory capital thresholds tend to adjust slowly downward toward their capital targets over time, while banks operating at or below regulatory capital thresholds tend to adjust quickly upward toward their internal capital targets over time. ${ }^{7}$ Hence, when we observe a decline in the capital ratio at a below-target bank, we take this as evidence of a negative and exogenous shock to its capital ratio- that is, the bank incurred an unexpected reduction in net income and/or an unexpected increase in assets large enough to more than offset its desired capital management goal of increasing its capital ratio. In contrast, when we observe a decline in the capital ratio at an above-target bank, it is not clear whether this reduction is due to unexpected shocks to its net income or bank assets, a deliberate downward adjustment in the capital ratio by bank management, or both.

2.3. Test for post-capital shock liquidity adjustments. Identification in our main tests relies on the observation of events that occur in three consecutive time periods. The ordering of these events is

\footnotetext{
${ }^{7}$ Berger, et al (2008) estimated an average annual adjustment speed of $57 \%$ for book value equity ratios at large U.S. bank holding companies (BHCs) between 1994 and 2006. Relative to the most highly capitalized banks in their data, they found that adequately capitalized banks adjusted toward their targets 13 to 27 percentage points faster; undercapitalized banks adjusted 31 percentage points faster; and significantly undercapitalized banks adjusted 65 percentage points faster.
} 
illustrated in Figure 2. In the earliest period, $t-2$, we observe whether bank $i$ 's equity capital ratio $K_{i, t-2}$ is below its internal capital ratio target $K^{*}$ i,t-2 $\left(\right.$ i.e., $G A P_{i, t-2}>0$ ). In the following period, $t-1$, we observe whether bank $i$ receives a capital ratio shock $\left(\operatorname{SHOCK}_{i, t-1}=1\right)$. In the third period, $t$, we observe the change in bank $i$ 's liquidity ratio $L_{i, t}$. The regression test is specified as follows:

$$
\Delta L_{i, t}=\alpha+\gamma \cdot \text { BELOW }_{i, t-2}+\delta \cdot \operatorname{SHOCK}_{i, t-1}+\pi \cdot D L_{i, t-1}+F_{i}+S_{j}+T_{t}+\varepsilon_{i, t}
$$

where $B E L O W_{i, t-2}=1$ if bank $i$ is below its capital ratio target at $t-2$, the vector $D L_{i, t-1}$ is comprised of bank-specific liquidity determinants, $F_{i}, S_{j}$ and $T_{t}$ are fixed bank, State and time effects, respectively, and $\varepsilon_{i, t}$ is a symmetric random error term. Given our definition of $S H O C K$, only banks that are below their capital targets can experience a negative capital shock; we include the BELOW dummy to absorb any non-SHOCK-related tendencies for liquidity $L$ to increase or decrease for these below-capital target banks. We estimate this equation using ordinary least squares techniques.

Our main test variable $\delta$ indicates whether and how the average bank adjusts its liquidity position when under equity capital stress (i.e., experiencing a deterioration of its equity capital while operating below its internal capital ratio target). Given that the model includes a one-period lag of the dependent variable, $\delta>0$ indicates a positive change in $L$ during time period $t$ (substitutes), while $\delta<0$ indicates a negative change in $L$ during time period $t$ (complements). More formally, the sign of $\delta$ allows us to test for and/or discriminate among the following null hypothesis and alternative hypotheses:

$\mathrm{H}($ null): $\quad$ There is no relationship between bank equity capital ratios and bank liquidity levels $(\delta=0)$.

$\mathrm{H}$ (substitutes): At the margin, banks treat equity capital ratios and liquidity levels as substitutes $(\delta>0)$.

$\mathrm{H}$ (complements): At the margin, banks treat equity capital ratios and liquidity levels as complements $(\delta<0)$. 
Before proceeding further, we must clarify the manner in which we are using the words 'substitutes' and 'complements.' Liquidity and solvency are separate financial concepts; in the strictest sense, a bank cannot substitute a dollar of liquidity for a dollar of solvency or vice versa. We use these terms as convenient and compact language to describe whether bank solvency and bank liquidity tend to vary positively or negatively - that is, as complements in practice or as substitutes in practice. Moreover, our methodology is designed to capture changes in bank liquidity associated with exogenous shocks to bank solvency, so that any observed complementarity or substitutability in the data is not merely capturing the movement of some third causal factor that drives both liquidity and solvency.

\section{Data and variables}

We estimate our two-stage methodology using an annual 1998-2012 data panel on U.S. bank holding companies (BHCs). The data are taken from the Federal Reserve Y9-C database, which is publicly available online. For the remainder of the paper, we use the terms BHCs, banks, and banking companies interchangeably.

We begin with all bank-year observations. We then exclude any individual bank-year observation that has one or more of the following characteristics: The BHC is very small (assets less than $\$ 100$ million), the BHC is foreign-controlled (foreign ownership stake exceeds 10\%), or the BHC made a substantial acquisition (annual asset growth exceeds 25\%). These exclusions leave us with an unbalanced panel of 10,807 bank-year observations. All variables that we construct from these data are winsorized at the $1^{\text {st }}$ and $99^{\text {th }}$ percentiles of the sample distribution. Table 1 displays descriptive statistics and definitions for all of the variables in our main data set.

3.1. Estimating capital targets and shocks. Using the approach outlined in equations (1) through (7), we estimate the capital ratio targets $K^{*}$ for each banking company in each year of the data, using two different definitions of capital. TIER12/RWA* is the internal target for each bank's regulatory capital ratio TIER12/RWA, which is the ratio of Tier 1 and Tier 2 equity to risk-weighted assets; we shall refer to this as the 'regulatory capital ratio'. EQ/ASSETS* is the internal target for each bank's 
accounting capital target EQ/ASSETS, which is the ratio of accounting equity to accounting assets; we shall refer to this as the 'accounting capital ratio'. ${ }^{8}$ We specify the vector $X_{i, t-1}$ with four bank-specific characteristics that are likely to influence banks' internal capital ratio targets: The natural log of bank asset size (InASSETS), the standard deviation of bank return on assets (SDROA), a too-big-to-fail indicator variable identifying banks with more than $\$ 50$ billion in assets $(T B T F)$, and a publicly traded indicator variable (LISTED). We specify the vector $Z_{i, t-1}$ with three bank-specific characteristics that are likely to influence the speeds with which banks adjust their capital ratios toward their targets: InASSETS, LISTED, and $A B O V E$, the latter a dummy variable equal to one if a bank is operating above its internal capital ratio target (i.e., $G A P_{t-1}<0$ ). We also include fixed bank effects and fixed year effects in these estimations.

The results of the first-stage partial adjustment estimations are displayed in Table 2. The magnitudes of the estimated capital targets are reasonable, with TIER12/RWA* and EQ/ASSETS* averaging $16.85 \%$ and $7.81 \%$, respectively, across the entire sample period. As shown in Table 3, capital targets remained relatively stable during our 1998-2012 sample period. Targets trended upward by about 50 basis points from 1998 to 2005, retrenched just prior to and during the financial crisis, and then stabilized at new sample period highs after the crisis had run its course. Sensibly, the annual percentage of banks suffering negative shocks to regulatory capital (TIER12/RWA) was substantially higher in and around the financial crisis, reaching global highs of 34\% to $42 \%$ between 2006 and 2009, but shocks to the backstop accounting capital ratio (EQ/ASSETS) were distributed seemingly randomly across our sample period. The economic magnitudes of the negative shocks to regulatory capital were non-trivial, ranging between 75 to 138 basis points per year on average.

The estimated adjustment speed parameters $\lambda$ are relatively small. For TIER12/RWA, banks closed only about $15.1 \%$ of the gap between their actual and target capital ratios in the average year; for

\footnotetext{
${ }^{8}$ Even though our 'accounting capital ratio' is defined nearly identically to the regulatory 'leverage ratio' (Tier 1 equity capital/assets), we prefer to think of it as an accounting concept for two reasons. First, both banking companies and non-banking companies have always paid attention to this accounting ratio; indeed, financial analysts refer to the inverse of this ratio as the 'equity multiplier.' Second, both banks and bank regulators in the U.S. consider the leverage ratio to be a secondary, or backstop, capital threshold; indeed, our empirical results are strongly consistent with this notion.
} 
EQ/ASSETS, banks closed about $16.0 \%$ of this gap on average. These estimated adjustment speeds are substantially lower than the $45 \%$ to $55 \%$ speeds found in some previous banking studies (e.g., Berger, et al 2008, Flannery and Rangan 2010). There are two explanations for these contrasting results. First, these two previous studies included only banking companies listed on public equity markets, while we include both listed and non-listed banks in our models. Because publicly traded banks can raise new, or retire existing, equity capital shares far more easily than privately held banks, one would expect faster capital adjustment speeds at these banks. Second, the data sets used in these two previous studies ended before the financial crisis. During the crisis, a number of phenomena occurred that may have contributed to slower capital adjustment at U.S. banks. The decline in bank stock prices made raising new equity capital very expensive; large year-over-year financial losses at many banks created wide gaps between actual and target capital ratios, so that a given amount of newly raised capital closed only a smaller percentage of that wider gap; and lingering uncertainty about the details of the asset-purchase and/or capital-injection policies of the U.S. Treasury may have caused banks to put their own capital adjustment activities on hold.

The estimated coefficients in our partial adjustment models have mostly intuitive signs, though not always statistically significant. In the capital target equations (Steps 1 and 3), the publicly traded dummy LISTED carries the expected negative coefficient. Publicly traded firms can raise new equity capital quickly when needed, so we would expect them to set lower internal capital targets. After controlling for the capital-raising advantage of listed banks—-which are almost exclusively large and very large banks-larger banks (InASSETS) tend to set higher capital targets. This result is consistent with any number of non-mutually exclusive phenomena, including holding extra capital to protect greater franchise values, holding extra capital to fund acquisition opportunities, or holding extra capital against risks that tend to be associated with larger banks (e.g., market risk, off-balance sheet) that are not specified in our model. This result also suggests that any size-based diversification advantages are relatively small at the banks in our sample (which excludes the very small U.S. banks that are not organized within holding company structures). The coefficients on the TBTF dummy are never statistically significant; the 
straightforward interpretation is that while too-big-to-fail effects are likely to reduce the cost of capital at these banking companies, the quantity of capital is uninfluenced. The negative coefficient on the earnings volatility variable SDROA is non-intuitive; one would expect banks with volatile earnings to hold additional equity capital cushions against losses. Berger, et al (2008) also fail to find the expected positive coefficient using a similar capital adjustment model. ${ }^{9}$

In the adjustment speed regressions (Step 2), the coefficient signs are not robust across the two models. In the regulatory capital model, the coefficients are statistically significant with reasonable signs. Listed banks have faster adjustment speeds, consistent with their access to liquid public equity markets. The adjustment speed at listed banks is 0.039 larger (faster) than at non-listed banks, on average. After controlling for the capital-raising advantage of (mainly large) listed banks, larger banks adjust more slowly, perhaps indicating scale diseconomies to raising large amounts of capital in private markets. A doubling of asset size is associated with a 0.041 reduction in adjustment speed $(-0.059 * \ln 2)$. Finally, consistent with the prior literature, adjustments speeds are highly asymmetric. On average, adjustment speeds for banks operating above their internal capital targets are 0.257 smaller (slower) than adjustment speeds at banks operating below their internal targets. In the accounting capital model, these coefficients remain statistically significant but have all flipped signs. Although the results from Steps 1 and 3 indicate that banks set their regulatory and accounting capital targets similarly, the results in Step 2 indicate that banks manage (i.e., adjustments toward the targets) their regulatory and accounting capital ratios dissimilarly. As we shall see, these dissimilarities carry over into banks' liquidity reactions to negative capital shocks.

3.2. Specifying the second stage equation. We test our main hypothesis in equation (9). In our baseline specifications of equation (9), we define the dependent variable $L$ as the net stable funding ratio (NSFR). Basel III defines the NSFR as the ratio of 'available stable funding' (a weighted sum of various

\footnotetext{
${ }^{9}$ These non-intuitive results may be capturing product mix effects. DeYoung and Roland (2001), Demirgüç-Kunt and Huizinga (2010), and others show that revenue volatility is positively associated with activities against which banks do not (or are not required to) hold much equity capital, e.g., fee income from investment banking, securities brokerage, and other financial services activities.
} 
items on the right-hand side of the bank balance sheet, weighted by increasing maturity and/or stability) to 'required stable funding' (a weighted sum of various items on the left-hand side of the bank balance sheet, weighted by increasing maturity and/or illiquidity). Hence, a higher value for NSFR indicates a more liquid bank and less liquidity risk. Basel III set the weights so that NSFR $=100 \%$ would indicate a just-adequate liquidity position — that is, available stable funding is just equal to required stable funding. Our 1998-2012 sample period predates the implementation of the NFSR rules in the U.S., and published bank regulatory data from those years do not include all of the balance sheet items necessary to calculate NSFR exactly. We use the formulaic approach of DeYoung and Jang (2016), which has been shown to generate distributions of NSFR values for U.S. banks that closely match distributions generated by European banks monitored by the Bank for International Settlements (2013).

The average bank-year value for NSFR in our data is $118.71 \%$. Hence, the majority of U.S. banking companies met or exceeded this regulatory threshold between 1998 and 2012. ${ }^{10}$ Nevertheless, NFSR exhibits substantial and systematic variation across both time and bank size, as shown in Figure 1. Small banks with assets less than $\$ 1$ billion have tended to operate well above the NSFR $\geq 1$ threshold, even during the liquidity pressures that arose during the financial crisis. In contrast, larger banks have on average operated closer to or below the NSFR $\geq 1$ threshold.

We also use two additional definitions of banks' liquidity positions in our tests. First, because equity capital is included as 'available stable funding' in the Basel III definition of NSFR, the estimated coefficient $\delta$ in equation (5) may carry a negative bias due to the purely mechanical relationship between NSFR and SHOCK. To neutralize this possibility, we calculate an adjusted version of NSFR that excludes equity from the numerator (NSFR_ADJ) and use this adjusted version in our tests. Second, because the net stable funding ratio is a new and not yet well understood measure of bank liquidity, we run alternative specifications in which we replace NSFR with more traditional liquidity measures. COREDEPS/LOANS is the ratio of core deposits (transactions deposits and small time deposits) to total

\footnotetext{
${ }^{10}$ DeYoung and Jang (2016) show that the NSFR is more likely to fall below $100 \%$ for large U.S. banks, and that the NSFR for U.S. banks of all sizes tended to decline leading up to, and increase after, the 2008-2009 financial crisis.
} 
loans, and LIQUID/ASSETS is the ratio of liquid assets (cash, reserves held at the Federal Reserve, fed funds sold, reverse repurchase agreements, and Treasury securities) to total assets. Like NSFR, both COREDEPS/LOANS and LIQUID/ASSETS are increasing indicators of bank liquidity. ${ }^{11}$

The primary test variable in our baseline estimations of equation (9) is the negative capital shock dummy SHOCK. As previously discussed above, we define a negative capital shock as a bank-year observation during which an already capital-deficient bank (i.e., a bank operating below its internal equity capital ratio target) experiences a shock that causes it to fall further below its internal equity capital ratio target. We also construct three alternative sets of test variables. SHOCKSIZE is a continuous variable that measures the decline in a bank's equity capital ratio due to a negative shock. $\operatorname{SHOCK}(0 \%-1 \%)$, $\operatorname{SHOCK}(1 \%-2 \%)$, and $\operatorname{SHOCK}(>2 \%)$ are dummy variables equal to one if the capital shock is, respectively, less than 100 basis points, between 100 and 200 basis points, or more than 200 basis points. SHORTFALL SMALL (SHORTFALL LARGE) is a dummy variable equal to one if the capital shock left a bank with a $G A P$ at $t-1$ that was smaller than (larger than) the median value for all banks experiencing capital shortfalls. We include these SHORTFALL variables to test whether banks' liquidity responses are sensitive not just to the size of the capital shocks, but also to the size of the internal capital shortfalls (i.e., $\left.G A P_{t-1}\right)$ that result from the shock. Finally, we measure all of the above test variables twice: One version based on a shock to the regulatory capital ratio TIERI2/RWA and a second version based on a shock to the accounting capital ratio EQ/ASSETS.

Logically, a negative shock to a bank's equity capital ratio can occur either because the bank's net income (and thus retained earnings) is lower than expected and/or because its assets (or risk-based assets) increase unexpectedly. Of the 3,068 bank-year shocks to TIERI2/RWA in our data, $85.07 \%$ of the shocked bank experienced net income lower than that year's industry mean, with $10.4 \%$ experiencing negative net income. In the denominator, $59.22 \%$ of these shocked banks experienced asset growth

\footnotetext{
${ }^{11}$ The COREDEPS/LOANS ratio is simply the inverse of the 'loans-to-core deposits ratio' that has long been used by bankers to measure the liquidity of their balance sheets.
} 
greater than that year's industry mean, with $58.93 \%$ experiencing asset growth at least one standard deviation greater than the industry mean.

We specify equation (9) parsimoniously. As described above, we include the dummy variable $B E L O W$ to absorb any tendencies for the liquidity ratios at below-target banks to increase or decrease, independent of negative capital shocks. We also include InASSETS and LISTED to control for potential differences in liquidity management practices at large banks and/or publicly traded banks. Finally, we include bank and State fixed effects as well as time fixed effects.

\section{Main results}

Our baseline results are displayed in Table 4, where the capital shock variables are based on the regulatory capital ratio TIER12/RWA. ${ }^{12}$ Each of the specifications is estimated three times: For the full sample of BHCs in our data, for a subsample of small BHCs (assets less than \$1 billion), and for a subsample of larger BHCs (assets greater than $\$ 1$ billion).

On average, the results suggest that capital-deficient banks (i.e., banks operating below their internal risk-weighted equity capital targets) treat their regulatory capital ratios and their liquidity ratios as substitutes. After controlling for the underlying effects of being below their internal capital target $(B E L O W)$, the average bank responded to a negative capital shock (SHOCK) by increasing its net stable funding ratio by 0.398 during the following year (column 1). This result is not present for banks with assets more than $\$ 1$ billion (column 2), but is driven by the smaller community banks (column 3). In addition, the significantly positive coefficient on $B E L O W$ indicates that small banks operating below their desired capital levels have a natural tendency to increase their liquidity positions independent of receiving a negative capital shock. Summing the coefficients on BELOW and SHOCK in column 3 tells us that the average capital-deficient community bank that receives a negative capital shock increases its NSFR by

\footnotetext{
${ }^{12}$ The results in Table 4 are statistically and economically robust to (a) replacing the total risk-weighted capital ratio TIERI2/RWA with the Tier 1 risk-weighted capital ratio TIERI/RWA, and (b) replacing the total adjusted net stable funding ratio NSFR_ADJ with the unadjusted net stable funding ratio NSFR. Results available upon request.
} 
1.344 during the following year, an approximate 1.28 percentage point change in the sample average NSFR_ADJ.

At just slightly more than one percentage point of $N F S R$, one may interpret this result as a relatively small economic effect. But for the purposes of our present analysis, the size of the measured effect is far less important than its direction. A statistically positive coefficient on SHOCK allows us to reject not only the zero null, but also allows us to reject the possibility that the true coefficient sign is negative and with it the alternative hypothesis under which banks treat equity and liquidity as complements. Thus, the data are consistent with the notion that, when a bank operating closer than it prefers (i.e., below its own internal target) to the minimum regulatory capital threshold experiences an exogenous reduction in equity capital, it treats equity capital and liquidity as substitutes, not as complements.

The increases in banks' liquidity positions are not linearly related to the size of capital shock (SHOCKSIZE). The substitution effect is 0.461 when the negative shock to TIERI2/RWA is less than 100 basis points, increases to 0.765 when the negative shock is between 100 and 200 basis points, but is statistically zero for negative shocks in excess of 200 basis points (column 9). These are reasonable findings: Larger shocks to capital require larger operational response, but increasingly larger capital shocks at some point become so financially disruptive that normal operational responses (such as liquidity-capital substitution) are infeasible. Similarly, the responses of shocked banks were larger when the shock left them especially far below their internal capital targets (SHORTFALL LARGE).

Among the remaining control variables, publicly traded banks (LISTED) tend to operate with more liquidity than privately held banks. The most straightforward interpretation is that equity market investors penalize liquidity risk and hence, at the margin, create incentives for banks to maintain liquidity. Note that this result is operative only for the subsample of community banks; compared to small listed banks, large listed banks often have access to public credit markets and other sources of quick credit that reduce the necessity for holding liquidity. After controlling for listed versus non-listed status, we find no relationship between the size of a bank (InASSETS) and its liquidity positions. 
In Table 5 we repeat our tests using the accounting capital ratio EQ/ASSETS (replacing the regulatory capital ratio TIERI2/RWA) to measure the negative capital shock variables. The results are telling and the implications are important. The coefficients on the capital shock variables are statistically indistinguishable from zero in all of these tests. From this we can conclude that the positive liquidity responses in Table 4 are not driven per se by the negative equity capital shocks, but rather because a larger capital shock increases a bank's likelihood of violating a minimum regulatory capital constraint. ${ }^{13}$ This implies the existence of a synergy from imposing joint capital and liquidity constraints on banks: The presence of regulatory capital constraints, which are designed to mitigate the risk of insolvency, can under some conditions also serve to mitigate the risk of illiquidity.

Our results are robust to replacing the dependent variable NFSR_ADJ with the more traditional balance sheet liquidity measures LIQUID/ASSETS and COREDEPS/LOANS. In Table 6, the coefficient on SHOCK is statistically positive for negative shocks to TIER12/RWA, but not for negative shocks to EQ/ASSETS, and tends to be stronger for the smaller banks with assets less than $\$ 1$ billion. The coefficients on $B E L O W$ also continue to be statistically positive for the subsample of small banks, but again only when this variable is defined relative to banks' internal TIER12/RWA targets. Thus, our results are consistent with the findings of DeYoung and Jang (2015) that liquidity management at U.S. banks prior to Basel III focused on maintaining targeted levels of traditional liquidity ratios, but by construction those policies were consistent with maintaining targeted levels of the NSFR.

In the above tests, our identification scheme rests on the assumption that a reduction in a bank's equity capital ratio constitutes an exogenous shock when it is observed at a bank that is already operating below its internal capital ratio target. We test the validity of this identifying assumption in Table 7, where we define a negative capital shock as a reduction in TIER12/RWA for banks operating above (rather than below) their internal capital ratio targets. We run this placebo test for both the full data sample and for

\footnotetext{
${ }^{13}$ Our EQ/ASSETS accounting ratio is nearly identical in construction to the Tier 1 capital/unweighted assets 'leverage ratio' that U.S. bank regulators included as part of their capital policies during most of our sample period. However, the minimum leverage ratio threshold was imposed as a 'backstop' to the Basel risk-weighted capital minimums; at only $3 \%$ for U.S. bank holding companies, this backstop became binding only for BHCs experiencing substantial capital distress.
} 
the small bank subsample, as these are the data for which we find evidence of capital-liquidity substitution in Table 5. These tests provide support for our identifying assumption, as they generate no evidence linking bank liquidity positions to reductions in bank capital ratios.

Conspicuous among our empirical findings is one non-result: We never reject the null hypothesis for the subsample of banks with assets greater than $\$ 1$ billion. Hence, we find no evidence that capital and liquidity are effective substitutes at larger banks. Two explanations come immediately to mind: Easier access to capital markets (a) affords larger banks the luxury of repairing their capital ratios more deliberately than smaller banks, and (b) allows larger banks to repair their capital ratios without having to resort to balance sheet adjustments that, as a side effect, result in increased liquidity. We find evidence consistent with the former in our capital adjustment model (Table 2), where TIER12/RWA adjustment speeds decline as banks grow larger. We find evidence consistent with the latter in our transmission channel tests below (Table 8). In terms of policy, this non-result has a straightforward interpretation: Because we cannot reject the possibility that large bank liquidity management is unaffected by the presence of a minimum capital standard, then any regulatory effort to mitigate liquidity risk at these banks likely requires a separate liquidity regulation, one example being the combination of separate liquidity and capital constraints in Basel III. In contrast, our results indicate that the presence of a minimum capital standard at least partially mitigates liquidity risk at small banks.

4.1. Transmission channels. Do banks respond to negative equity capital shocks by purposefully demanding higher levels of liquidity? If so, we would observe shocked banks taking direct actions to increase liquidity—for example, increasing the share of stable (core) deposits in their deposit mixes. Or rather, do banks respond to negative equity capital shocks by taking actions designed to repair their declining capital ratios, but which also have the fortuitous ancillary effect of increasing their liquidity positions? If so, we would observe shocked banks making post-shock adjustments to their capital ratios-for example, shrinking their total assets and/or reducing the share of assets with high regulatory risk weights.

To investigate these questions, we estimate the following set of straightforward equations: 


$$
\triangle \text { CHANNEL }_{i, t}=\alpha+\gamma \cdot B E L O W_{i, t-2}+\delta \cdot S H O C K_{i, t-1}+\theta \cdot M E A N \_C H A N N E L_{i, t-1}+F_{i}+S_{j}+T_{t}+\varepsilon_{i, t}
$$

where the dependent variable $\triangle C H A N N E L$ is defined six different ways. We specify two channels through which banks would respond if their primary objective in response to the capital shock is to enhance their liquidity positions: By reducing their dividend payout ratios ( $\triangle P A Y O U T$ RATIO) and by increasing the share of core deposits in their total deposits ( $\triangle C O R E$ DEPOSITS/DEPOSITS). We specify four channels through which banks would respond if their primary objective in response to the capital shock is to enhance their capital ratio: By reducing asset growth (\% $\triangle A S S E T S)$, by reducing the asset share of total loans or high-risk weight loans (LLOANS/ASSETS, ABUSINESS LOANS/ASSETS), or by reducing the potential increase in high-risk weighted asset growth (LLOAN COMMITMENTS/ASSETS). The test variable is SHOCK (or SHOCKSIZE), defined on the regulatory capital ratio TIER12/RWA. The controls include the BELOW dummy, the industry mean of the dependent variable (MEAN_LCHANNEL) to absorb trends in banks' financial conditions, as well as bank, state and time fixed effects.

The results are displayed in Table 8 for the small bank and larger bank subsamples. The results strongly suggest that the "ancillary changes in liquidity" story is the best way to interpret our earlier findings that liquidity and equity capital ratios are substitutes in practice. For the small bank subsample, the coefficients on SHOCK and/or SHOCKSIZE indicate that negative capital shocks are associated with slower asset growth, fewer total loans and business loans, fewer loan commitments, and smaller dividend payouts (top panel, columns 1 through 8 ). By the adding-up constraint, the negative changes in LOANS/ASSETS and BUSINESS LOANS/ASSETS must be accompanied by increases in other categories of bank assets, most of which are more liquid than loans or business loans (e.g., cash, fed funds sold, government securities, retail loans). While the primary explanation for the negative change in DIVIDEND PAYOUT RATIO is cash retention and hence increased balance sheet liquidity, increasing cash also results in an improved risk-based capital ratio. The coefficients on CORE DEPOSITS/DEPOSITS are never statistically significant, an indication that banks do not respond to 
negative capital shocks with pure liquidity-enhancing actions, but rather that banks' liquidity positions improve in the process of addressing their capital shortfalls. We find only a single liquidity-enhancing response to negative capital shocks for the larger bank subsample, a reduction in loan commitments.

The channels we identify here-connecting equity capital ratios and liquidity ratios for U.S. banking companies between 1998 and 2012 - are strikingly similar to the channels identified by Calomiris and Wilson (2004) for U.S. banking companies during the 1920s and 1930s. Throughout the economically strong 1920s, banks increased both their equity capital and their asset risk (loans-to-assets) on average; that is, banks effectively substituted equity capital for liquidity. Throughout the economically weak 1930s, banks with high default risk (stress on equity capital) reduced their dividend payouts on average; that is, banks effectively substituted liquidity for equity capital. That these similarities exist at U.S. banks nearly a century removed from each other-despite intervening institutional changes such as deposit insurance, tighter regulatory and supervisory oversight, and a myriad of market-based alternatives for both bank borrowers and bank depositors—strongly suggests that the liquidity-capital relationships that we find in our data represent fundamental regularities in bank behavior.

4.2. Additional tests. The synergistic relationship between risk-weighted capital regulations and enhanced bank liquidity appears only for the subsample of banks with assets less than $\$ 1$ billion; on average, we find no evidence of these synergies among larger banks. Given that this is a size-based phenomenon, one might expect our findings to be even stronger among the very smallest banks. In Table 9 we split the small bank subsample into two halves by annual median asset size (on average, approximately $\$ 442$ million) and then re-estimate our baseline model. The liquidity responses of the smaller and larger community banks to negative equity shocks are very similar. However, the coefficient on $B E L O W$ is statistically significant only for the smaller set of community banks, and is substantially larger than in the whole-sample regressions. For example, summing the coefficients on BELOW and SHOCK in column 2 tells us that the average small capital-deficient community bank that receives a negative capital shock increases its NSFR by 1.789 during the following year. 
Table 9 also double-checks the non-result that we find for the subsample of larger banks with assets greater than $\$ 1$ billion. Dividing our sample at $\$ 1$ billion is a convenience, as this corresponds to one of the traditional size-based definitions of a 'community bank.' However, while it is accurate to describe the above- $\$ 1$ billion subsample as containing 'larger' banks, this is a poor lower size threshold for defining 'large' banks. In columns 7, 8 and 9 we estimate our model for a subsample of large banks with assets greater than $\$ 10$ billion. Again, we find no statistically significant liquidity responses to negative capital shocks at these banks. ${ }^{14}$

Our methodological approach is predicated on the proximity of a bank's actual equity capital ratio to its internal equity capital ratio target. This contrasts with an important earlier literature-dating back to Merton (1978), Marcus (1983, 1984), Furlong and Keeley (1987, 1989, 1990), and Keeley (1990)— that focused on the proximity of a bank's actual equity capital ratio to zero (insolvency) and/or to the minimum thresholds set by bank regulators. In Table 10, we split the small bank subsample into two halves by annual median TIERI2/RWA (on average, approximately 14\%) and then re-estimate our baseline model. Our baseline findings are both robust and economically stronger for the subsample of community banks with above-median risk-based equity capital ratios. When these more highly capitalized banks received a negative capital shock, NSFR increased in response by a full percentage point on average (columns 1, 3 and 7), independent of any non-shock-related tendencies to increase their liquidity positions $(B E L O W)$. It is important to note that a bank in the high equity ratio subsample can experience a negative capital shock only if it has set a high internal capital ratio target. Thus, these results are consistent with banks taking actions to protect their high franchise values. Our baseline findings vanish for the low-capital ratio subsample of community banks; thus, for these banks we find no evidence that equity capital and liquidity are either substitutes or complements in practice.

\footnotetext{
${ }^{14}$ Moving the subsample threshold substantially higher than $\$ 10$ reduced the number of observations needed for responsible estimation and inference.
} 


\section{Summary and conclusions}

For nearly three decades, financial regulators around the world have required their banks to maintain minimum capital ratios as established under the first and second Basel Accords. The Basel III Accord not only increased these minimum capital thresholds, but for the first time mandated minimum liquidity standards — the Liquidity Coverage Ratio (LCR) and the Net Stable Funding Ratio (NSFR)—for banks in its signatory nations, to be implemented gradually between 2015 and 2019. Going forward, banks will have to manage their balance sheets under two constraints rather than just one. Whether and how this new system of joint constraints will impact bank behavior (most importantly, bank credit supply), the behavior of nonbank lenders, and/or spillover into financial markets is uncertain. An emerging empirical literature is attempting to answer such questions, but has thus far reached nothing close to an empirical consensus. In this paper, we attempt to gain some insight by studying the liquidity behavior of U.S. bank holding companies that experienced negative exogenous shocks to their equity capital ratios between 1998 and 2012.

We face two empirical challenges. First, we can only observe data on bank liquidity and bank capital in a pre-Basel III world, when regulation required minimum capital levels but did not require minimum liquidity levels. We design an empirical strategy that uses bank financial statement data from this single-constraint environment to infer how banks are likely to manage their capital and liquidity positions under the coming joint-constraint environment. In essence, we must draw our conclusions by testing whether pre-Basel III banks were already behaving in a manner consistent with Basel III liquidity regulations. Second, changes in bank capital ratios may be endogenous to changes in liquidity ratios, via balance sheet identities or in-common correlations with various determinants of bank performance. We identify plausibly exogenous changes in bank capital ratios based on the following logic: If a bank that is already operating below its own internal capital ratio target—which we estimate for each bank and year using standard partial adjustment modeling techniques—suffers an additional capital reduction that moves it even further below its target, we assume the capital reduction was involuntary and thus constitutes an exogenous shock. 
On average, the evidence indicates that banks increased their NSFRs following negative shocks to their risk-based regulatory capital ratios. In contrast, we find no evidence that these same banks increased their NFSRs following negative shocks to their simple accounting (leverage) equity ratios. Together, these two results imply that U.S. banking companies have historically treated capital and liquidity as substitutes, and that this relationship (a) is predicated on the existence of potentially binding regulatory capital minimums but (b) does not require the existence of regulatory liquidity minimums. Our results are driven mainly by the data on so-called 'community banks' with assets less than $\$ 1$ billion—banks that tend to have highly liquid balance sheets even in the absence of capital shocks, and in any case exhibit little if any systemic risk. Thus, these results provide support for the Federal Reserve's policy of exempting small banks from the Basel III liquidity requirements, and challenge the one-size-fits-all implementation policies of the European Banking Authority.

We make no claims that these banks are responding to negative equity capital shocks by demanding more liquidity. Rather, we find evidence consistent with the notion that banks respond to negative equity capital shocks by taking actions to repair their declining capital ratios, and that these actions have the fortuitous ancillary effect of also increasing bank liquidity. Capital-shocked community banks reduce their asset growth rates, their percentage of assets invested in total loans, the percentage of their assets invested in loans with high capital risk weights, their commitments to make future loans, and their dividend payout ratios. Each of these actions contributes to upward adjustments to risk-based capital ratios; the latter four actions also result in increased bank liquidity positions. Thus, the systematic responses of small U.S. banking companies to negative capital shocks documented here have both an upside and a downside: Positive prudential synergies from increased bank liquidity, and macro-economic costs associated with reduced credit supply. 


\section{References}

Acharya, Viral V., Hamid Mehran and Anjan V. Thakor. 2010. "Caught Between Scylla and Charybdis? Regulating Bank Leverage when there is Rent Seeking and Risk Shifting." Federal Reserve Bank of Cleveland Working Paper No. 10-24, revised in 2015.

Aiyar, Shekhar, Charles Calomiris and Tomasz Wieladek. 2014. "Does Macro-Prudential Regulation Leak? Evidence from a UK Policy Experiment.” Journal of Money, Credit and Banking 46: 181214.

Basel Committee on Banking Supervision. 2013. "Basel III monitoring report," Bank for International Settlements, September.

Basel Committee on Banking Supervision. 2016. "Literature review on integration of regulatory capital and liquidity instruments," Bank for International Settlements, Working Paper No 30.

Berger, Allen N., and Christa H.S. Bouwman. 2009. Bank Liquidity Creation. Review of Financial Studies 22(9):3779-3837.

Berger, Allen, Robert DeYoung, Mark Flannery, David Lee, Özde Öztekin. 2008. "How Do Large Banking Companies Manage Their Capital?” Journal of Financial Services Research 34: 123-149.

Birn, Martin, Michel Dietsch, and Dominique Durant. 2015. "How banks proceed to reach the four Basel III ratios at the same time? Modeled and observed analysis," Bank for International Settlements, unpublished manuscript.

Blundell, Richard and Stephen Bond. 1998. "Initial conditions and moment restrictions in dynamic panel data models." Journal of Econometrics 87: 115-143.

Bouwman, Christa H.S. 2015. "Liquidity: How Banks Create it and How It Should Be Regulated," in The Oxford Handbook of Banking, Second Edition, pp. 184-218, ed: Allen Berger, Philip Molyneux, John Wilson, Oxford: Oxford University Press.

Bryant, John, 1980, “A Model of Reserves, Bank Runs and Deposit Insurance,” Journal of Banking and Finance 4: 335-344.

Calomiris, Charles W., Florian Heider and Marie Hoerova. 2013. “A Theory of Bank Liquidity Requirements.” Columbia Business School Research Paper No. 14-39, revised in 2015.

Calomiris, Charles W. and Berry Wilson. 2004. "Bank Capital and Portfolio Management: The 1930s 'Capital Crunch' and the Scramble to Shed Risk.” Journal of Business 77: 421-455.

Demirgüç-Kunt, Asli and Harry Huizinga. 2010. "Bank Activity and Funding Strategies: The Impact on Risk and Returns.” Journal of Financial Economics 98: 226-650.

DeYoung, Robert and Karen Y. Jang. 2016. "Do Banks Actively Manage their Liquidity?” Journal of Banking and Finance 66: 143-161.

DeYoung, Robert and Karen P. Roland. 2001. "Product Mix and Earnings Volatility at Commercial Banks: Evidence from a Degree of Leverage Model," Journal of Financial Intermediation 10: 5484. 
Diamond, Douglas W. and Philip H. Dybvig. 1983. "Bank Runs, Deposit Insurance, and Liquidity," The Journal of Political Economy 91: 401-419.

Distinguin, Isabelle, Caroline Roulet, and Amine Tarazi. 2013. "Bank regulatory capital and liquidity: Evidence from US and European publicly traded banks," Journal of Banking and Finance 37: 3295-3317.

Flannery, Mark and Kristine Watson Hankins. 2013. "Estimating dynamic panel models in corporate finance," Journal of Corporate Finance 19: 1-19.

Flannery, Mark, Kasturi Rangan. 2010. "What caused the bank capital build-up of the 1990s?” Review of Finance 14: 587-622.

Flannery, Mark, Kasturi Rangan. 2006. "Partial adjustment toward target capital structures." Journal of Financial Economics 79: 469-506.

Furlong, Frederick T. and Michael C. Keeley. 1987. "Bank capital regulation and asset risk," Economic Review, Federal Reserve Bank of San Francisco, Spring: 20-40.

Furlong, Frederick T. and Michael C. Keeley. 1989. "Capital regulation and bank risk-taking: A note," Journal of Banking \& Finance 13: 883-891.

Furlong, Frederick T. and Michael C. Keeley. 1990. "Bank capital regulation," Journal of Banking and Finance 14: 69-84.

Imbierowicz, Björn and Christian Rauch. 2014. "The Relationship between Liquidity Risk and Credit Risk in Banks. Journal of Banking and Finance 40: 242-256.

Keeley, Michael C. 1990. "Deposit insurance, risk and market power in banking", American Economic Review 80: 1183-1200.

Klein, Michael. 1971. "A theory of the banking firm.” Journal of Money, Credit and Banking 3: 205-218.

Lemmon, Michael, Michael Roberts, Jamie Zender. 2008. "Back to the beginning: Persistence and the cross-section of corporate capital structure." Journal of Finance 63: 1575-1608.

Marcus, Alan. J. 1983. "The Bank Capital Decision: A Time Series-Cross Section Analysis," Journal of Finance 38: 1217-1232.

Marcus, Alan. J. 1984. "Deregulation of bank financial policy," Journal of Banking and Finance 8: 557565.

Merton, Robert C. 1978. "On the costs of deposit insurance when there are surveillance costs," Journal of Business 51: 439-452.

Monti, Mario. 1972. "Deposit, credit, and interest rate determination under alternative bank objectives", in Karl Shell and Giorgio P. Szego, editors, Mathematical Methods in Investment and Finance, North-Holland, Amsterdam, 431- 454. 
Schmaltz, Christian, Sebastian Pokutta, Thomas Heidorn, and Silvio Andrae. 2014. "How to make regulators and shareholders happy under Basel III," Journal of Banking and Finance 46: 311-325.

Walther, Ansgar. 2016. "Jointly optimal regulation of bank capital and maturity structure." Journal of Money, Credit and Banking 48: 415-448. 
Table 1: Summary Statistics. Data are an unbalanced panel of 10,807 bank-year observations for U.S. BHCs between 1998 and 2012 . Each variable is winsorized at the $1^{\text {st }}$ and $99^{\text {th }}$ percentiles of the sample distributions.

\begin{tabular}{|c|c|c|c|c|c|}
\hline & & mean & sd & $\min$ & $\max$ \\
\hline \multicolumn{6}{|l|}{ Capital ratios and targets: } \\
\hline TIERI2/RWA (\%) & (Tier $1+$ Tier 2 capital) / risk-weighted assets & 14.907 & 4.74 & 6.2 & 37.40 \\
\hline$\triangle T I E R 12 / R W A$ & annual change in TIERI2/RWA & 0.054 & 1.53 & -5.0 & 5.17 \\
\hline EQ/ASSETS $(\%)$ & equity / total assets & 9.157 & 2.69 & 2.6 & 18.34 \\
\hline$\triangle E Q / A S S E T S$ & annual change in EQ/ASSETS & 0.021 & 0.86 & -2.9 & 2.71 \\
\hline TIER12/RWA*(\%) & estimated TIER12/RWA target & 16.852 & 3.11 & 9.5 & 21.74 \\
\hline EQ/ASSETS* $(\%)$ & estimated EQ/ASSETS target & 7.810 & 3.32 & 1.1 & 11.70 \\
\hline \multicolumn{6}{|l|}{ Dependent variables: } \\
\hline$N S F R \_A D J$ & net stable funding ratio adjusted for equity & 105.076 & 16.77 & 66.8 & 189.81 \\
\hline$\triangle N S F R \_A D J$ & annual change in NSFR_ADJ & -0.485 & 6.15 & -21.01 & 17.30 \\
\hline COREDEPS/LOANS & core deposits / loans $\#^{\#}$ & 107.215 & 31.08 & 50.3 & 269.46 \\
\hline$\triangle C O R E D E P S / L O A N S$ & annual change in COREDEPS/LOANS & -0.168 & 10.23 & -34.27 & 29.66 \\
\hline LIQUID/ASSETS & liquid assets / assets $\#$ & 14.158 & 10.61 & 1.1 & 56.61 \\
\hline$\triangle L I Q U I D / A S S E T S$ & annual change in LIQUID/ASSETS & -1.003 & 4.24 & -17.76 & 9.68 \\
\hline$\% \triangle \operatorname{ASSETS}(\%)$ & annual percentage asset growth & 3.661 & 7.52 & -18.4 & 23.31 \\
\hline$\triangle L O A N S / A S S E T S$ & annual change in loans-to-assets ratio & -0.004 & 4.15 & -11.3 & 10.93 \\
\hline$\triangle B U S I N E S S$ LOANS/ASSETS & annual change in business loans to assets ratio & -0.156 & 1.72 & -6.3 & 5.41 \\
\hline$\triangle L O A N$ COMMITMENTS/ASSETS & annual change in loan commitments to assets ratio & 0.103 & 2.87 & -9.7 & 9.89 \\
\hline$\triangle D I V I D E N D$ PAYOUT RATIO & annual change in dividends/net income & 0.555 & 49.60 & -229.10 & 211.59 \\
\hline$\triangle C O R E D E P S / D E P O S I T S$ & annual change in core deposits to deposits ratio & -0.176 & 3.19 & -10.3 & 10.56 \\
\hline \multicolumn{6}{|l|}{ Explanatory variables: } \\
\hline BELOW_TIER12/RWA & $=1$ if TIER12/RWA $<$ TIER12/RWA* (at t-2) & 0.676 & 0.47 & 0.0 & 1.00 \\
\hline BELOW_EQ/ASSETS & $=1$ if EQ/ASSETS $<$ EQ/ASSETS* $($ at $t-2)$ & 0.475 & 0.50 & 0.0 & 1.00 \\
\hline ABOVE_TIERI2RWA & $=1$ if $\mathrm{TIER} 12 / \mathrm{RWA}>\mathrm{TIER} 12 / \mathrm{RWA}^{*}($ at $\mathrm{t}-1)$ & 0.506 & 0.50 & 0.0 & 1.00 \\
\hline$A B O V E \_E Q T A$ & $=1$ if EQ/ASSETS $>$ EQ/ASSETS* (at $t-1)$ & 0.525 & 0.50 & 0.0 & 1.00 \\
\hline ASSETS $(\$ 1000$, lagged $)$ & Total assets & $6.33 * 10^{6}$ & $7.55^{*} 10^{7}$ & $114,098.6$ & $2.25 * 10^{9}$ \\
\hline $\ln A \operatorname{SSETS}(\$ 1000$, lagged $)$ & Natural logarithm of total assets & 13.614 & 1.19 & 11.7 & 21.53 \\
\hline TBTF (lagged) & Dummy for BHCs with more than $\$ 50$ billion in assets & 0.015 & 0.12 & 0.0 & 1.00 \\
\hline LISTED (lagged) & Dummy for publicly traded BHCs & 0.281 & 0.45 & 0.0 & 1.00 \\
\hline SDROA (lagged) & Standard deviation of ROA over the preceding 16 quarters & 0.412 & 0.16 & 0.0 & 1.58 \\
\hline
\end{tabular}

(continued) 


\begin{tabular}{|c|c|c|c|c|c|}
\hline & & mean & sd & $\min$ & $\max$ \\
\hline \multicolumn{6}{|l|}{ Test variables: } \\
\hline SHOCK_TIERI2/RWA & $\begin{array}{l}=1 \text { if BELOW_TIER } 12 / \mathrm{RWA}=1 \text { (at } \mathrm{t}-2) \text { and } \text { TIER } 12 / \mathrm{RWA} \text { declines } \\
\text { (in t-1) and the BHC's GAP became larger during t-1 }\end{array}$ & 0.284 & 0.45 & 0.0 & 1.00 \\
\hline SHOCK_EQ/ASSETS & $\begin{array}{l}=1 \text { if BELOW_EQ/ASSETS }=1 \text { (at } \mathrm{t}-2) \text { and } \mathrm{EQ} / \mathrm{ASSETS} \text { declines (in } \\
\mathrm{t}-1) \text { and the BHC's GAP became larger during } \mathrm{t}-1\end{array}$ & 0.181 & 0.39 & 0.0 & 1.00 \\
\hline SHOCKSIZE_TIERI2/RWA & Reduction in TIER12/RWA when SHOCK_TIER12/RWA = 1 & 0.265 & 0.64 & 0.0 & 4.96 \\
\hline SHOCKSIZE_EQ/ASSETS & Reduction in EQ/ASSETS when SHOCK_EQ/ASSETS = 1 & 0.106 & 0.33 & 0.0 & 2.93 \\
\hline $\operatorname{SHOCK}(0 \%-1 \%) \_T I E R 12 / R W A$ & $\begin{array}{l}=1 \text { if } S H O C K_{-} \text {TIER } 12 / R W A=1 \text { and } \text { TIER12/RWA declines (in t-1) } \\
\text { by less than } 1 \text { percentage point }\end{array}$ & 0.189 & 0.39 & 0.0 & 1.00 \\
\hline $\operatorname{SHOCK}(1 \%-2 \%) \_T I E R 12 / R W A$ & $\begin{array}{l}=1 \text { if } S H O C K_{-} \text {TIERI2/RWA = } 1 \text { and TIER12/RWA declines (in } \mathrm{t}-1 \text { ) } \\
\text { by between } 1 \text { and } 2 \text { percentage points }\end{array}$ & 0.064 & 0.24 & 0.0 & 1.0 \\
\hline SHOCK(>2\%)_TIERI2/RWA & $\begin{array}{l}=1 \text { if } S H O C K_{-} \text {TIER } 12 / R W A=1 \text { and } \text { TIER } 12 / \text { RWA declines (in } \mathrm{t}-1 \text { ) } \\
\text { by more than } 2 \text { percentage points }\end{array}$ & 0.03 & 0.17 & 0.0 & 1.0 \\
\hline SHOCK $(0 \%-1 \%) \_E Q / A S S E T S$ & $\begin{array}{l}=1 \text { if } S H O C K_{-} E Q / A S S E T S=1 \text { and } \mathrm{EQ} / \mathrm{ASSETS} \text { declines (in t-1) by } \\
\text { less than } 1 \text { percentage point }\end{array}$ & 0.153 & 0.36 & 0.0 & 1.00 \\
\hline SHOCK(1\%-2\%)_EQ/ASSETS & $\begin{array}{l}=1 \text { if } S H O C K_{-} E Q / A S S E T S=1 \text { and } \mathrm{EQ} / \mathrm{ASSETS} \text { declines (in } \mathrm{t}-1 \text { ) by } \\
\text { between } 1 \text { and } 2 \text { percentage points }\end{array}$ & 0.021 & 0.14 & 0.0 & 1.0 \\
\hline SHOCK $(>2 \%) \_E Q / A S S E T S$ & $\begin{array}{l}=1 \text { if } S H O C K_{-} E Q / A S S E T S=1 \text { and } \mathrm{EQ} / \mathrm{ASSETS} \text { declines (in } \mathrm{t}-1 \text { ) by } \\
\text { more than } 2 \text { percentage points }\end{array}$ & 0.007 & 0.08 & 0.0 & 1.00 \\
\hline SHORTFALL SMALL_TIERI2/RWA & $\begin{array}{l}=1 \text { if } S H O C K_{-} \text {TIER } 12 / R W A=1 \text { and } \mathrm{GAP}_{\mathrm{t}-1} \text { is lower than the median } \\
\text { value }(5.05)\end{array}$ & 0.148 & 0.36 & 0.0 & 1.99 \\
\hline SHORTFALL LARGE_TIER12/RWA & $\begin{array}{l}=1 \text { if } S H O C K_{-} \text {TIER } 12 / R W A=1 \text { and } \mathrm{GAP}_{\mathrm{t}-1} \text { is greater than the median } \\
\text { value }(5.05)\end{array}$ & 0.136 & 0.34 & 0.00 & 4.96 \\
\hline SHORTFALL SMALL_EQ/ASSETS & $\begin{array}{l}=1 \text { if } S H O C K_{-} E Q / A S S E T S=1 \text { and } \mathrm{GAP}_{\mathrm{t}-1} \text { is lower than the median } \\
\text { value }(1.90)\end{array}$ & 0.088 & 0.28 & 0.0 & 1.99 \\
\hline SHORTFALL LARGE_EQ/ASSETS & $\begin{array}{l}=1 \text { if } S H O C K \_E Q / A S S E T S=1 \text { and } \mathrm{GAP}_{\mathrm{t}-1} \text { is greater than the median } \\
\text { value }(1.90)\end{array}$ & 0.093 & 0.29 & 0.0 & 2.93 \\
\hline
\end{tabular}


Table 2: Partial adjustment model for TIER12/RWA and EQ/ASSETS. Parameters for the three-step partial adjustment model, estimated for an unbalanced panel of 10,807 bank-year observations for U.S. BHCs between 1998 and 2012. Models are estimated with fixed bank effects and fixed year effects. Step 1 estimates equation (3) using dynamic generalized method of moments techniques (Blundell and Bond 1998). Step 2 and Step 3 estimate equation (6) and equation (7) using ordinary least squares. All right-hand side variables are lagged one year.

\begin{tabular}{|c|c|c|c|c|c|c|c|}
\hline $\begin{array}{l}\text { Dependent } \\
\text { variable: }\end{array}$ & $\begin{array}{l}\text { TIERI2/RWA } \\
\text { Step 1 }\end{array}$ & $\begin{array}{c}\triangle T I E R 12 / R W A \\
\text { Step } 2 \\
\end{array}$ & $\begin{array}{c}\text { TIER12/RWA } t_{t^{-}} \\
\left(\text {TIER12/RWA } A_{t-1}\right) *\left(1-\widehat{\lambda_{l, t}}\right) \\
\text { Step } 3 \\
\end{array}$ & & $\begin{array}{c}\text { EQ/ASSETS } \\
\text { Step 1 } \\
\end{array}$ & $\begin{array}{c}\triangle E Q / A S S E T S \\
\text { Step } 2 \\
\end{array}$ & $\begin{array}{c}\text { EQ/ASSETS }{ }_{t}^{-} \\
\left(\text {EQ/ASSETS }_{t-1}\right) *\left(1-\widehat{\lambda_{l, t}}\right) \\
\text { Step 3 } \\
\end{array}$ \\
\hline$T 1 E R 1 / 2 R W A(t-1)$ & $\begin{array}{c}0.892^{* * * *} \\
(24.95)\end{array}$ & & & $\operatorname{EQ/ASSETS}(t-1)$ & $\begin{array}{c}0.915^{* * * *} \\
(34.23)\end{array}$ & & \\
\hline InASSETS & $\begin{array}{c}0.321 * * \\
(2.19)\end{array}$ & $\begin{array}{c}-0.059 * * * \\
(-5.36)\end{array}$ & $\begin{array}{c}1.363 * * * \\
(27.90)\end{array}$ & InASSETS & $\begin{array}{c}0.147^{* *} \\
(1.99)\end{array}$ & $\begin{array}{c}0.014^{*} \\
(1.90)\end{array}$ & $\begin{array}{c}0.626^{* * * *} \\
(12.92)\end{array}$ \\
\hline LISTED & $\begin{array}{c}-0.704 * * \\
(-2.32)\end{array}$ & $\begin{array}{c}0.039 * * * \\
(5.40)\end{array}$ & $\begin{array}{l}-0.700 \\
(-0.72)\end{array}$ & LISTED & $\begin{array}{c}-0.680 * * * \\
(-2.64)\end{array}$ & $\begin{array}{c}-0.135^{* * *} \\
(-5.97)\end{array}$ & $\begin{array}{c}-3.667 * * * \\
(-2.88)\end{array}$ \\
\hline TBTF & $\begin{array}{l}-0.876 \\
(-1.18)\end{array}$ & & $\begin{array}{l}6.813 \\
(1.17)\end{array}$ & $T B T F$ & $\begin{array}{l}-0.165 \\
(-0.48)\end{array}$ & & $\begin{array}{l}0.541 \\
(0.38)\end{array}$ \\
\hline$S D R O A$ & $\begin{array}{l}0.098 \\
(0.30)\end{array}$ & & $\begin{array}{c}-4.236 * * * \\
(-2.95)\end{array}$ & SDROA & $\begin{array}{l}0.246 \\
(1.17)\end{array}$ & & $\begin{array}{c}-3.483 * * * \\
(-3.23)\end{array}$ \\
\hline$A B O V E$ & & $\begin{array}{c}-0.257 * * * \\
(-9.57)\end{array}$ & & $A B O V E$ & & $\begin{array}{c}0.085^{* * * *} \\
(4.48)\end{array}$ & \\
\hline constant & $\begin{array}{l}-2.676 \\
(-1.31)\end{array}$ & $\begin{array}{c}1.070 * * * \\
(6.50)\end{array}$ & $\begin{array}{c}-0.604 * * * \\
(-8.41)\end{array}$ & constant & $\begin{array}{l}-1.196 \\
(-1.10)\end{array}$ & $\begin{array}{l}-0.036 \\
(-0.36)\end{array}$ & $\begin{array}{c}0.384 * * * \\
(3.96)\end{array}$ \\
\hline$\lambda$ & 0.108 & 0.151 & & $\lambda$ & 0.085 & 0.160 & \\
\hline $\begin{array}{l}K^{*} \\
\mathrm{~N}\end{array}$ & $\begin{array}{l}14.036 \\
10,807\end{array}$ & 10,807 & $\begin{array}{l}16.852 \\
10,807\end{array}$ & $\begin{array}{l}K^{*} \\
\mathrm{~N}\end{array}$ & $\begin{array}{c}8.341 \\
10,807\end{array}$ & 10,807 & $\begin{array}{c}7.810 \\
10,807\end{array}$ \\
\hline
\end{tabular}


Table 3: Targets for and shocks to TIER12/RWA and EQ/ASSETS. Annual means for estimated capital ratio targets $\left(K^{*}\right)$, percentage of banks experiencing negative capital shocks each year (SHOCK), and annual mean sizes of those shocks (SHOCKSIZE). Unbalanced panel of 10,807 bank-year observations for U.S. BHCs between 1998 and 2012.

\begin{tabular}{|c|c|c|c|c|c|c|}
\hline & \multicolumn{3}{|c|}{ TIER12/RWA } & \multicolumn{3}{|c|}{ EQ/ASSETS } \\
\hline & mean $K^{*}$ & $\begin{array}{c}\% \text { of BHCs } \\
\text { suffering } \\
\text { SHOCK } \\
\end{array}$ & $\begin{array}{c}\text { mean } \\
\text { SHOCKSIZE }\end{array}$ & mean $K^{*}$ & $\begin{array}{c}\% \text { of BHCs } \\
\text { suffering } \\
\text { SHOCK }\end{array}$ & $\begin{array}{c}\text { mean } \\
\text { SHOCKSIZE }\end{array}$ \\
\hline 1998 & 16.52 & $22.62 \%$ & 1.08 & 7.67 & $8.37 \%$ & 0.53 \\
\hline 1999 & 16.66 & $28.89 \%$ & 0.98 & 7.80 & $13.88 \%$ & 0.49 \\
\hline 2000 & 16.75 & $33.45 \%$ & 0.88 & 7.93 & $26.96 \%$ & 0.67 \\
\hline 2001 & 16.76 & $32.43 \%$ & 0.90 & 7.95 & $12.91 \%$ & 0.46 \\
\hline 2002 & 16.73 & $27.54 \%$ & 0.90 & 7.90 & $17.27 \%$ & 0.51 \\
\hline 2003 & 16.74 & $22.63 \%$ & 0.75 & 7.89 & $12.36 \%$ & 0.50 \\
\hline 2004 & 16.93 & $23.87 \%$ & 0.83 & 8.12 & $17.19 \%$ & 0.46 \\
\hline 2005 & 17.03 & $31.69 \%$ & 0.89 & 8.23 & $20.49 \%$ & 0.44 \\
\hline 2006 & 16.59 & $34.17 \%$ & 0.71 & 7.26 & $23.62 \%$ & 0.45 \\
\hline 2007 & 16.73 & $35.06 \%$ & 0.77 & 7.40 & $19.97 \%$ & 0.45 \\
\hline 2008 & 16.68 & $42.21 \%$ & 0.89 & 7.33 & $16.23 \%$ & 0.49 \\
\hline 2009 & 16.87 & $39.21 \%$ & 1.18 & 7.50 & $28.82 \%$ & 0.84 \\
\hline 2010 & 17.11 & $24.52 \%$ & 1.29 & 7.69 & $22.61 \%$ & 0.97 \\
\hline 2011 & 17.22 & $14.36 \%$ & 1.31 & 7.82 & $19.93 \%$ & 0.67 \\
\hline 2012 & 17.21 & $14.31 \%$ & 1.38 & 7.82 & $10.56 \%$ & 0.95 \\
\hline
\end{tabular}


Table 4: Second-stage estimates for liquidity NSFR_ADJ and regulatory capital ratio target TIER12/RWA*. Parameters for equation (9), estimated for an unbalanced panel of 10,807 bank-year observations for U.S. BHCs between 1998 and 2012. Models are estimated with fixed bank effects, fixed State effects, and fixed year effects, using ordinary least squares. BELOW is lagged two years. All other right-hand side variables are lagged one year.

\begin{tabular}{|c|c|c|c|c|c|c|c|c|c|c|c|c|}
\hline Sample: & $\begin{array}{c}\text { [1] } \\
\text { All banks } \\
\end{array}$ & $\begin{array}{c}{[2]} \\
\text { Assets > } \\
\$ 1 \text { billion } \\
\end{array}$ & $\begin{array}{c}{[3]} \\
\text { Assets < } \\
\text { \$1 billion } \\
\end{array}$ & $\begin{array}{c}\text { [4] } \\
\text { All banks } \\
\end{array}$ & $\begin{array}{c}5] \\
\text { Assets > } \\
\text { \$1 billion } \\
\end{array}$ & $\begin{array}{c}6] \\
\text { Assets < } \\
\$ 1 \text { billion } \\
\end{array}$ & $\begin{array}{c}\text { [7] } \\
\text { All banks } \\
\end{array}$ & $\begin{array}{c}8] \\
\text { Assets > } \\
\$ 1 \text { billion } \\
\end{array}$ & $\begin{array}{c}9] \\
\text { Assets }< \\
\$ 1 \text { billion } \\
\end{array}$ & $\begin{array}{c}\text { [10] } \\
\text { All banks } \\
\end{array}$ & $\begin{array}{c}{[11]} \\
\text { Assets > } \\
\$ 1 \text { billion } \\
\end{array}$ & $\begin{array}{c}{[12]} \\
\text { Assets < } \\
\$ 1 \text { billion } \\
\end{array}$ \\
\hline BELOW & $\begin{array}{c}0.694 * * \\
(2.41)\end{array}$ & $\begin{array}{l}0.333 \\
(0.72)\end{array}$ & $\begin{array}{c}0.805 * * \\
(2.08)\end{array}$ & $\begin{array}{c}0.793 * * * \\
(2.81)\end{array}$ & $\begin{array}{l}0.337 \\
(0.75)\end{array}$ & $\begin{array}{c}0.950 * * \\
(2.51)\end{array}$ & $\begin{array}{c}0.701 * * \\
(2.43)\end{array}$ & $\begin{array}{l}0.345 \\
(0.75)\end{array}$ & $\begin{array}{c}0.804 * * \\
(2.08)\end{array}$ & $\begin{array}{c}0.730 * * \\
(2.48)\end{array}$ & $\begin{array}{l}0.369 \\
(0.79)\end{array}$ & $\begin{array}{c}0.839 * * \\
(2.12)\end{array}$ \\
\hline SHOCK & $\begin{array}{c}0.398 * * * \\
(2.77)\end{array}$ & $\begin{array}{l}0.155 \\
(0.61)\end{array}$ & $\begin{array}{c}0.539 * * * \\
(3.01)\end{array}$ & & & & & & & & & \\
\hline SHOCKSIZE & & & & $\begin{array}{l}0.108 \\
(0.93)\end{array}$ & $\begin{array}{l}0.145 \\
(0.63)\end{array}$ & $\begin{array}{l}0.145 \\
(1.05)\end{array}$ & & & & & & \\
\hline $\operatorname{SHOCK}(0 \%-1 \%)$ & & & & & & & $\begin{array}{c}0.339 * * \\
(2.23)\end{array}$ & $\begin{array}{l}0.105 \\
(0.40)\end{array}$ & $\begin{array}{c}0.461 * * \\
(2.40)\end{array}$ & & & \\
\hline $\operatorname{SHOCK}(1 \%-2 \%)$ & & & & & & & $\begin{array}{c}0.577 * * \\
(2.26)\end{array}$ & $\begin{array}{l}0.101 \\
(0.21)\end{array}$ & $\begin{array}{c}0.765 * * \\
(2.49)\end{array}$ & & & \\
\hline $\operatorname{SHOCK}(>2 \%)$ & & & & & & & $\begin{array}{l}0.206 \\
(0.49)\end{array}$ & $\begin{array}{l}0.199 \\
(0.25)\end{array}$ & $\begin{array}{l}0.422 \\
(0.84)\end{array}$ & & & \\
\hline SHORTFALL SMALL & & & & & & & & & & $\begin{array}{l}0.260 \\
(1.36)\end{array}$ & $\begin{array}{c}0.0100 \\
(0.03)\end{array}$ & $\begin{array}{c}0.414^{*} \\
(1.71)\end{array}$ \\
\hline SHORTFALL LARGE & & & & & & & & & & $\begin{array}{c}0.541 * * * \\
(2.88)\end{array}$ & $\begin{array}{l}0.312 \\
(0.82)\end{array}$ & $\begin{array}{c}0.669 * * * \\
(3.03)\end{array}$ \\
\hline $\ln A S S E T S$ & $\begin{array}{l}-0.574 \\
(-1.27)\end{array}$ & $\begin{array}{l}-0.111 \\
(-0.13)\end{array}$ & $\begin{array}{l}-0.788 \\
(-1.28)\end{array}$ & $\begin{array}{l}-0.565 \\
(-1.25)\end{array}$ & $\begin{array}{l}-0.087 \\
(-0.10)\end{array}$ & $\begin{array}{l}-0.779 \\
(-1.27)\end{array}$ & $\begin{array}{l}-0.572 \\
(-1.26)\end{array}$ & $\begin{array}{l}-0.104 \\
(-0.12)\end{array}$ & $\begin{array}{l}-0.787 \\
(-1.28)\end{array}$ & $\begin{array}{l}-0.575 \\
(-1.27)\end{array}$ & $\begin{array}{c}-0.0685 \\
(-0.08)\end{array}$ & $\begin{array}{l}-0.817 \\
(-1.33)\end{array}$ \\
\hline LISTED & $\begin{array}{c}1.748 * * * \\
(3.89)\end{array}$ & $\begin{array}{l}0.452 \\
(0.51)\end{array}$ & $\begin{array}{c}2.214 * * * \\
(3.94)\end{array}$ & $\begin{array}{c}1.710 * * * \\
(3.80)\end{array}$ & $\begin{array}{l}0.447 \\
(0.51)\end{array}$ & $\begin{array}{c}2.179 * * * \\
(3.85)\end{array}$ & $\begin{array}{c}1.744 * * * \\
(3.87)\end{array}$ & $\begin{array}{l}0.442 \\
(0.50)\end{array}$ & $\begin{array}{c}2.203^{* * *} * \\
(3.92)\end{array}$ & $\begin{array}{c}1.780 * * * \\
(3.93)\end{array}$ & $\begin{array}{l}0.488 \\
(0.54)\end{array}$ & $\begin{array}{c}2.235^{* * * *} \\
(3.97)\end{array}$ \\
\hline constant & $\begin{array}{l}10.40^{*} \\
(1.66)\end{array}$ & $\begin{array}{l}4.188 \\
(0.31)\end{array}$ & $\begin{array}{l}13.224 \\
(1.62)\end{array}$ & $\begin{array}{l}10.257 \\
(1.64)\end{array}$ & $\begin{array}{l}3.796 \\
(0.28)\end{array}$ & $\begin{array}{l}13.055 \\
(1.60)\end{array}$ & $\begin{array}{c}10.386^{*} \\
(1.66)\end{array}$ & $\begin{array}{l}4.080 \\
(0.31)\end{array}$ & $\begin{array}{l}13.220 \\
(1.62)\end{array}$ & $\begin{array}{l}10.38^{*} \\
(1.66)\end{array}$ & $\begin{array}{l}3.501 \\
(0.26)\end{array}$ & $\begin{array}{l}13.57 * \\
(1.67)\end{array}$ \\
\hline $\mathrm{N}$ & 10,807 & 3,123 & 7,684 & 10,807 & 3,123 & 7,684 & 10,807 & 3,123 & 7,684 & 10807 & 3123 & 7684 \\
\hline Adjusted R-squared & 0.181 & 0.209 & 0.164 & 0.181 & 0.209 & 0.163 & 0.181 & 0.209 & 0.164 & 0.182 & 0.209 & 0.164 \\
\hline
\end{tabular}


Table 5: Second-stage estimates for liquidity $N S F R \_A D J$ and accounting capital ratio target $E Q / A S S E T S *$. Parameters for equation (9), estimated for an unbalanced panel of 10,807 bank-year observations for U.S. BHCs between 1998 and 2012. Models are estimated with fixed bank effects, fixed State effects, and fixed year effects, using ordinary least squares. BELOW is lagged two years. All other right-hand side variables are lagged one year.

\begin{tabular}{|c|c|c|c|c|c|c|c|c|c|c|c|c|}
\hline Sample: & $\begin{array}{c}\text { [1] } \\
\text { All banks }\end{array}$ & $\begin{array}{c}2] \\
\text { Assets > } \\
\text { \$1 billion }\end{array}$ & $\begin{array}{c}3] \\
\text { Assets < } \\
\$ 1 \text { billion }\end{array}$ & $\begin{array}{c}4] \\
\text { All banks }\end{array}$ & $\begin{array}{c}5] \\
\text { Assets > } \\
\$ 1 \text { billion }\end{array}$ & $\begin{array}{c}6] \\
\text { Assets < } \\
\$ 1 \text { billion }\end{array}$ & $\begin{array}{c}\text { [7] } \\
\text { All banks }\end{array}$ & $\begin{array}{c}8] \\
\text { Assets > } \\
\$ 1 \text { billion }\end{array}$ & $\begin{array}{c}9] \\
\text { Assets < } \\
\$ 1 \text { billion }\end{array}$ & $\begin{array}{c}\text { [10] } \\
\text { All banks }\end{array}$ & $\begin{array}{c}11] \\
\text { Assets > } \\
\$ 1 \text { billion }\end{array}$ & $\begin{array}{c}12] \\
\text { Assets < } \\
\$ 1 \text { billion }\end{array}$ \\
\hline BELOW & $\begin{array}{l}-0.245 \\
(-0.95)\end{array}$ & $\begin{array}{l}-0.426 \\
(-0.64)\end{array}$ & $\begin{array}{l}-0.230 \\
(-0.77)\end{array}$ & $\begin{array}{l}-0.161 \\
(-0.63)\end{array}$ & $\begin{array}{l}-0.310 \\
(-0.46)\end{array}$ & $\begin{array}{l}-0.141 \\
(-0.48)\end{array}$ & $\begin{array}{l}-0.249 \\
(-0.97)\end{array}$ & $\begin{array}{c}-0.432 \\
(60.66)\end{array}$ & $\begin{array}{l}-0.234 \\
(-0.79)\end{array}$ & $\begin{array}{l}-0.233 \\
(-0.90)\end{array}$ & $\begin{array}{l}-0.464 \\
(-0.69)\end{array}$ & $\begin{array}{l}-0.213 \\
(-0.72)\end{array}$ \\
\hline SHOCK & $\begin{array}{l}0.203 \\
(1.14)\end{array}$ & $\begin{array}{l}0.165 \\
(0.43)\end{array}$ & $\begin{array}{l}0.250 \\
(1.24)\end{array}$ & & & & & & & & & \\
\hline SHOCKSIZE & & & & $\begin{array}{l}-0.133 \\
(-0.49)\end{array}$ & $\begin{array}{l}-0.252 \\
(-0.41)\end{array}$ & $\begin{array}{l}-0.109 \\
(-0.36)\end{array}$ & & & & & & \\
\hline $\operatorname{SHOCK}(0 \%-1 \%)$ & & & & & & & $\begin{array}{l}0.200 \\
(1.12)\end{array}$ & $\begin{array}{l}0.211 \\
(0.57)\end{array}$ & $\begin{array}{l}0.229 \\
(1.11)\end{array}$ & & & \\
\hline $\operatorname{SHOCK}(1 \%-2 \%)$ & & & & & & & $\begin{array}{l}0.505 \\
(1.10)\end{array}$ & $\begin{array}{l}0.328 \\
(0.33)\end{array}$ & $\begin{array}{l}0.689 \\
(1.29)\end{array}$ & & & \\
\hline $\operatorname{SHOCK}(>2 \%)$ & & & & & & & $\begin{array}{l}-0.738 \\
(-0.64)\end{array}$ & $\begin{array}{l}-0.919 \\
(0.40)\end{array}$ & $\begin{array}{l}-0.852 \\
(-0.65)\end{array}$ & & & \\
\hline SHORTFALL SMALL & & & & & & & & & & $\begin{array}{l}0.116 \\
(0.49)\end{array}$ & $\begin{array}{l}0.369 \\
(0.59)\end{array}$ & $\begin{array}{l}0.124 \\
(0.47)\end{array}$ \\
\hline SHORTFALL LARGE & & & & & & & & & & $\begin{array}{l}0.285 \\
(1.21)\end{array}$ & $\begin{array}{l}0.0562 \\
(0.13)\end{array}$ & $\begin{array}{l}0.390 \\
(1.39)\end{array}$ \\
\hline $\ln A S S E T S$ & $\begin{array}{l}-0.426 \\
(-0.95)\end{array}$ & $\begin{array}{l}-0.052 \\
(-0.06)\end{array}$ & $\begin{array}{l}-0.630 \\
(-1.03)\end{array}$ & $\begin{array}{l}-0.401 \\
(-0.89)\end{array}$ & $\begin{array}{l}-0.051 \\
(-0.06)\end{array}$ & $\begin{array}{l}-0.572 \\
(-0.93)\end{array}$ & $\begin{array}{l}-0.447 \\
(-0.99)\end{array}$ & $\begin{array}{l}-0.059 \\
(-0.07)\end{array}$ & $\begin{array}{c}-0.677 \\
(61.09)\end{array}$ & $\begin{array}{l}-0.426 \\
(-0.95)\end{array}$ & $\begin{array}{l}-0.0592 \\
(-0.07)\end{array}$ & $\begin{array}{l}-0.636 \\
(-1.04)\end{array}$ \\
\hline LISTED & $\begin{array}{c}1.295 * * * \\
(2.85)\end{array}$ & $\begin{array}{l}0.089 \\
(0.10)\end{array}$ & $\begin{array}{c}1.744 * * * \\
(3.25)\end{array}$ & $\begin{array}{c}1.266^{* * *} * \\
(2.77)\end{array}$ & $\begin{array}{l}0.064 \\
(0.07)\end{array}$ & $\begin{array}{c}1.705^{* * *} * \\
(3.15)\end{array}$ & $\begin{array}{c}1.302 * * * \\
(2.87)\end{array}$ & $\begin{array}{l}0.078 \\
(0.08)\end{array}$ & $\begin{array}{c}1.769 * * * \\
(3.30)\end{array}$ & $\begin{array}{c}1.306 * * * \\
(2.87)\end{array}$ & $\begin{array}{l}0.0759 \\
(0.08)\end{array}$ & $\begin{array}{c}1.753 * * * \\
(3.27)\end{array}$ \\
\hline constant & $\begin{array}{l}9.121 \\
(1.47)\end{array}$ & $\begin{array}{l}3.846 \\
(0.28)\end{array}$ & $\begin{array}{l}11.915 \\
(1.46)\end{array}$ & $\begin{array}{l}8.779 \\
(1.41)\end{array}$ & $\begin{array}{l}3.836 \\
(0.28)\end{array}$ & $\begin{array}{l}11.152 \\
(1.36)\end{array}$ & $\begin{array}{l}9.411 \\
(1.51)\end{array}$ & $\begin{array}{l}3.960 \\
(0.30)\end{array}$ & $\begin{array}{l}12.536 \\
(1.52)\end{array}$ & $\begin{array}{l}9.108 \\
(1.47)\end{array}$ & $\begin{array}{l}3.977 \\
(0.30)\end{array}$ & $\begin{array}{l}11.98 \\
(1.48)\end{array}$ \\
\hline $\mathrm{N}$ & 10,807 & 3,123 & 7,684 & 10,807 & 3,123 & 7,684 & 10,807 & 3,123 & 7,684 & 10807 & 3123 & 7684 \\
\hline Adjusted R-squared & 0.180 & 0.209 & 0.161 & 0.180 & 0.209 & 0.161 & 0.180 & 0.209 & 0.162 & 0.180 & 0.209 & 0.162 \\
\hline
\end{tabular}


Table 6: Second-stage estimates for alternative measures of bank liquidity. Parameters for equation (9), estimated for an unbalanced panel of 10,807 bank-year observations for U.S. BHCs between 1998 and 2012. Models are estimated with fixed bank effects, fixed State effects, and fixed year effects, using ordinary least squared techniques. BELOW is lagged two years. All other right-hand side variables are lagged one year.

\begin{tabular}{|c|c|c|c|c|c|c|c|c|c|c|c|c|}
\hline $\begin{array}{l}\text { Dependent variable: } \\
\text { Capital ratio: }\end{array}$ & \multicolumn{3}{|c|}{$\begin{array}{c}\text { LIQUID/ASSETS } \\
\text { TIERI2/RWA }\end{array}$} & \multicolumn{3}{|c|}{$\begin{array}{c}\text { COREDEPS/LOANS } \\
\text { TIERI2/RWA }\end{array}$} & \multicolumn{3}{|c|}{$\begin{array}{c}\text { LIQUID/ASSETS } \\
\text { EQ/ASSETS }\end{array}$} & \multicolumn{3}{|c|}{$\begin{array}{c}\text { COREDEPS/LOANS } \\
\text { EQ/ASSETS }\end{array}$} \\
\hline Sample: & All banks & $\begin{array}{l}\text { Assets }> \\
\$ 1 \text { billion } \\
\end{array}$ & $\begin{array}{l}\text { Assets }< \\
\$ 1 \text { billion } \\
\end{array}$ & All banks & $\begin{array}{l}\text { Assets > } \\
\$ 1 \text { billion } \\
\end{array}$ & $\begin{array}{l}\text { Assets }< \\
\$ 1 \text { billion }\end{array}$ & All banks & $\begin{array}{l}\text { Assets }> \\
\$ 1 \text { billion } \\
\end{array}$ & $\begin{array}{l}\text { Assets }< \\
\$ 1 \text { billion } \\
\end{array}$ & All banks & $\begin{array}{l}\text { Assets > } \\
\$ 1 \text { billion } \\
\end{array}$ & $\begin{array}{l}\text { Assets }< \\
\$ 1 \text { billion }\end{array}$ \\
\hline BELOW & $\begin{array}{c}0.463 * * * \\
(2.66)\end{array}$ & $\begin{array}{l}0.376 \\
(1.34)\end{array}$ & $\begin{array}{c}0.545^{* *} \\
(2.24)\end{array}$ & $\begin{array}{c}1.281 * * * \\
(2.66)\end{array}$ & $\begin{array}{r}1.168 \\
(1.64)\end{array}$ & $\begin{array}{l}1.133^{*} \\
(1.70)\end{array}$ & $\begin{array}{l}-0.0434 \\
(-0.24)\end{array}$ & $\begin{array}{l}-0.196 \\
(-0.45)\end{array}$ & $\begin{array}{l}-0.003 \\
(-0.01)\end{array}$ & $\begin{array}{l}-0.0103 \\
(-0.02)\end{array}$ & $\begin{array}{l}1.645 \\
(1.46)\end{array}$ & $\begin{array}{l}-0.218 \\
(-0.47)\end{array}$ \\
\hline SHOCK & $\begin{array}{c}0.394 * * * \\
(4.04)\end{array}$ & $\begin{array}{l}0.312 * \\
(1.89)\end{array}$ & $\begin{array}{c}0.455^{* * * *} \\
(3.69)\end{array}$ & $\begin{array}{l}0.255 \\
(1.09)\end{array}$ & $\begin{array}{l}-0.616 \\
(-1.47)\end{array}$ & $\begin{array}{c}0.737 * * \\
(2.56)\end{array}$ & $\begin{array}{l}-0.0609 \\
(-0.49)\end{array}$ & $\begin{array}{l}0.182 \\
(0.69)\end{array}$ & $\begin{array}{l}-0.125 \\
(-0.86)\end{array}$ & $\begin{array}{l}0.192 \\
(0.68)\end{array}$ & $\begin{array}{l}-0.344 \\
(-0.60)\end{array}$ & $\begin{array}{l}0.373 \\
(1.14)\end{array}$ \\
\hline $\ln A S S E T S$ & $\begin{array}{l}-0.340 \\
(-1.22)\end{array}$ & $\begin{array}{l}-0.735 \\
(-1.40)\end{array}$ & $\begin{array}{l}-0.126 \\
(-0.31)\end{array}$ & $\begin{array}{l}-0.209 \\
(-0.25)\end{array}$ & $\begin{array}{l}0.106 \\
(0.07)\end{array}$ & $\begin{array}{l}-0.392 \\
(-0.35)\end{array}$ & $\begin{array}{l}-0.221 \\
(-0.79)\end{array}$ & $\begin{array}{l}-0.643 \\
(-1.20)\end{array}$ & $\begin{array}{l}0.026 \\
(0.07)\end{array}$ & $\begin{array}{c}-0.0183 \\
(-0.02)\end{array}$ & $\begin{array}{l}0.255 \\
(0.15)\end{array}$ & $\begin{array}{l}-0.210 \\
(-0.19)\end{array}$ \\
\hline LISTED & $\begin{array}{c}0.739 * * * \\
(2.71)\end{array}$ & $\begin{array}{l}0.118 \\
(0.18)\end{array}$ & $\begin{array}{c}0.894 * * * \\
(2.63)\end{array}$ & $\begin{array}{c}2.363 * * * \\
(3.59)\end{array}$ & $\begin{array}{l}0.872 \\
(0.62)\end{array}$ & $\begin{array}{c}2.976^{* * *} \\
(3.36)\end{array}$ & $\begin{array}{l}0.410 \\
(1.45)\end{array}$ & $\begin{array}{l}-0.190 \\
(-0.26)\end{array}$ & $\begin{array}{c}0.538 * \\
(1.65)\end{array}$ & $\begin{array}{c}1.815 * * * \\
(2.73)\end{array}$ & $\begin{array}{l}1.405 \\
(0.89)\end{array}$ & $\begin{array}{c}2.352 * * * \\
(2.91)\end{array}$ \\
\hline constant & $\begin{array}{l}4.212 \\
(1.09)\end{array}$ & $\begin{array}{l}11.075 \\
(1.39)\end{array}$ & $\begin{array}{l}1.145 \\
(0.21)\end{array}$ & $\begin{array}{l}7.205 \\
(0.61)\end{array}$ & $\begin{array}{l}2.169 \\
(0.09)\end{array}$ & $\begin{array}{c}10.288 \\
(0.69)\end{array}$ & $\begin{array}{l}3.083 \\
(0.80)\end{array}$ & $\begin{array}{l}10.174 \\
(1.26)\end{array}$ & $\begin{array}{l}-0.371 \\
(-0.07)\end{array}$ & $\begin{array}{l}5.624 \\
(0.48)\end{array}$ & $\begin{array}{l}-0.272 \\
(-0.01)\end{array}$ & $\begin{array}{l}8.916 \\
(0.60)\end{array}$ \\
\hline $\mathrm{N}$ & 10,807 & 3,123 & 7,684 & 10,807 & 3,123 & 7,684 & 10,807 & 3,123 & 7,684 & 10,807 & 3,123 & 7,684 \\
\hline Adjusted R-squared & 0.177 & 0.216 & 0.170 & 0.187 & 0.232 & 0.164 & 0.174 & 0.204 & 0.165 & 0.186 & 0.204 & 0.162 \\
\hline
\end{tabular}


Table 7: Placebo tests for second-stage estimations. $S H O C K$ is specified for banks operating above $(A B O V E=1)$ their internal regulatory equity capital ratio targets. Models are estimated for an unbalanced panel of 10,807 bank-year observations for U.S. BHCs between 1998 and 2012. The SHOCK variable is based on TIER12/RWA. Models are estimated with fixed bank effects, fixed State effects, and fixed year effects, using ordinary least squared techniques. ABOVE is lagged two years. All other right-hand side variables are lagged one year.

\begin{tabular}{lcc}
\hline & {$[1]$} & {$[2]$} \\
& & Assets < \\
Sample: & All banks & $\$ 1$ billion \\
\hline ABOVE & $-0.939^{* * * *}$ & $-0.941^{* *}$ \\
& $(-2.95)$ & $(-2.28)$ \\
SHOCK & 0.169 & -0.102 \\
& $(0.75)$ & $(-0.37)$ \\
InASSETS & -0.564 & -0.787 \\
& $(-1.25)$ & $(-1.28)$ \\
LISTED & $1.705^{* * *}$ & $2.138^{* * *}$ \\
& $(3.79)$ & $(3.80)$ \\
constant & $11.109^{*}$ & $14.158^{*}$ \\
& $(1.77)$ & $(1.73)$ \\
N & 10,807 & 7.684 \\
Adjusted R-squared & 0.181 & 0.163 \\
\hline
\end{tabular}


Table 8: Asset growth and loan portfolio channels. Parameters for equation (10), estimated for an unbalanced panel of 10,807 bank-year observations for U.S. BHCs between 1998 and 2012. Models are estimated with fixed bank effects, fixed State effects, and fixed year effects using ordinary least square estimation techniques. The SHOCK variables are based on TIER12/RWA. BELOW is lagged two years. All other right-hand side variables are lagged one year.

\begin{tabular}{|c|c|c|c|c|c|c|c|c|c|c|c|c|}
\hline & [1] & [2] & [3] & [4] & {$[5]$} & [6] & [7] & [8] & [9] & [10] & [11] & [12] \\
\hline \multicolumn{13}{|c|}{ Panel A: BHCs with ASSETS $<\$ 1$ billion } \\
\hline Dependent variable: & \multicolumn{2}{|c|}{$\% \Delta \mathrm{ASSETS}$} & \multicolumn{2}{|c|}{$\triangle \mathrm{LOANS} / \mathrm{ASSETS}$} & \multicolumn{2}{|c|}{$\begin{array}{c}\triangle \mathrm{BUSINESS} \\
\text { LOANS/ASSETS }\end{array}$} & \multicolumn{2}{|c|}{$\begin{array}{c}\Delta \text { LOAN } \\
\text { COMMITMENTS/ } \\
\text { ASSETS }\end{array}$} & \multicolumn{2}{|c|}{$\begin{array}{c}\triangle \text { DIVIDEND } \\
\text { PAYOUT RATIO }\end{array}$} & \multicolumn{2}{|c|}{$\begin{array}{c}\triangle \text { CORE DEPOSITS/ } \\
\text { DEPOSITS }\end{array}$} \\
\hline BELOW & $\begin{array}{c}-1.178 * * * \\
(-3.21)\end{array}$ & $\begin{array}{c}-0.913^{* *} \\
(-2.49)\end{array}$ & $\begin{array}{l}-0.287 \\
(-1.13)\end{array}$ & $\begin{array}{r}-0.423^{*} \\
(-1.71)\end{array}$ & $\begin{array}{l}0.014 \\
(0.15)\end{array}$ & $\begin{array}{l}-0.036 \\
(-0.38)\end{array}$ & $\begin{array}{l}0.090 \\
(0.57)\end{array}$ & $\begin{array}{l}0.065 \\
(0.42)\end{array}$ & $\begin{array}{l}5.491 * * * \\
(2.80)\end{array}$ & $\begin{array}{c}4.512 * * \\
(2.34)\end{array}$ & $\begin{array}{l}0.246^{*} \\
(1.76)\end{array}$ & $\begin{array}{l}0.257 * \\
(1.88)\end{array}$ \\
\hline SHOCK & $\begin{array}{l}0.267 \\
(1.37)\end{array}$ & & $\begin{array}{c}-0.352 * * * \\
(-2.79)\end{array}$ & & $\begin{array}{c}-0.214 * * * \\
(-3.77)\end{array}$ & & $\begin{array}{c}-0.223 * * \\
(-2.53)\end{array}$ & & $\begin{array}{c}-4.734 * * * \\
(-2.94)\end{array}$ & & $\begin{array}{l}-0.052 \\
(-0.53)\end{array}$ & \\
\hline SHOCKSIZE & & $\begin{array}{c}-0.397 * * * \\
(-2.76)\end{array}$ & & $\begin{array}{l}0.000 \\
(0.01)\end{array}$ & & $\begin{array}{c}-0.078 * * \\
(-2.14)\end{array}$ & & $\begin{array}{c}-0.149 * * * \\
(-2.66)\end{array}$ & & $\begin{array}{l}-2.058 \\
(-1.55)\end{array}$ & & $\begin{array}{l}-0.076 \\
(-1.09)\end{array}$ \\
\hline$M E A N \_Y$ & $\begin{array}{l}0.734 * * * \\
(3.16)\end{array}$ & $\begin{array}{l}0.748 * * * \\
(3.23)\end{array}$ & $\begin{array}{l}0.814 * * * \\
(5.20)\end{array}$ & $\begin{array}{l}0.811 * * * \\
(5.16)\end{array}$ & $\begin{array}{l}0.547 \\
(1.64)\end{array}$ & $\begin{array}{l}0.552 \\
(1.65)\end{array}$ & $\begin{array}{l}0.287 \\
(0.86)\end{array}$ & $\begin{array}{l}0.298 \\
(0.90)\end{array}$ & $\begin{array}{c}-0.064 * \\
(-1.83)\end{array}$ & $\begin{array}{l}-0.064^{*} \\
(-1.84)\end{array}$ & $\begin{array}{l}0.541 \\
(0.62)\end{array}$ & $\begin{array}{l}0.561 \\
(0.64)\end{array}$ \\
\hline constant & $\begin{array}{l}-0.412 \\
(-0.89)\end{array}$ & $\begin{array}{l}-0.490 \\
(-1.07)\end{array}$ & $\begin{array}{c}-0.741 * * \\
(-2.22)\end{array}$ & $\begin{array}{c}-0.701 * * \\
(-2.12)\end{array}$ & $\begin{array}{c}-0.181 * * \\
(-1.97)\end{array}$ & $\begin{array}{l}-0.161 * \\
(-1.77)\end{array}$ & $\begin{array}{l}-0.014 \\
(-0.08)\end{array}$ & $\begin{array}{l}-0.005 \\
(-0.03)\end{array}$ & $\begin{array}{l}-2.587 \\
(-1.19)\end{array}$ & $\begin{array}{l}-2.188 \\
(-1.02)\end{array}$ & $\begin{array}{l}0.407 \\
(0.32)\end{array}$ & $\begin{array}{l}0.377 \\
(0.30)\end{array}$ \\
\hline $\mathrm{N}$ & 7,684 & 7,684 & 7,684 & 7,684 & 7,684 & 7,684 & 7,684 & 7,684 & 7,684 & 7,684 & 7,684 & 7,684 \\
\hline Adjusted R-squared & 0.102 & 0.104 & 0.129 & 0.128 & 0.029 & 0.027 & 0.070 & 0.070 & 0.005 & 0.005 & 0.084 & 0.084 \\
\hline \multicolumn{13}{|c|}{ Panel B: BHCs with ASSETS > \$1 billion } \\
\hline BELOW & $\begin{array}{l}-0.571 \\
(-1.17)\end{array}$ & $\begin{array}{l}-0.415 \\
(-0.85)\end{array}$ & $\begin{array}{c}-0.688 * * \\
(-2.44)\end{array}$ & $\begin{array}{c}-0.720 * * * \\
(-2.59)\end{array}$ & $\begin{array}{c}-0.235^{* *} \\
(-2.04)\end{array}$ & $\begin{array}{c}-0.246^{* *} \\
(-2.16)\end{array}$ & $\begin{array}{l}0.042 \\
(0.22)\end{array}$ & $\begin{array}{l}-0.027 \\
(-0.14)\end{array}$ & $\begin{array}{l}-6.782 \\
(-1.52)\end{array}$ & $\begin{array}{l}-5.543 \\
(-1.28)\end{array}$ & $\begin{array}{l}0.143 \\
(0.64)\end{array}$ & $\begin{array}{l}0.089 \\
(0.41)\end{array}$ \\
\hline SHOCK & $\begin{array}{l}0.123 \\
(0.35)\end{array}$ & & $\begin{array}{l}-0.040 \\
(-0.23)\end{array}$ & & $\begin{array}{l}0.021 \\
(0.28)\end{array}$ & & $\begin{array}{c}-0.317 * * \\
(-2.25)\end{array}$ & & $\begin{array}{l}2.215 \\
(0.78)\end{array}$ & & $\begin{array}{l}-0.116 \\
(-0.66)\end{array}$ & \\
\hline SHOCKSIZE & & $\begin{array}{l}-0.405 \\
(-1.33)\end{array}$ & & $\begin{array}{l}0.067 \\
(0.49)\end{array}$ & & $\begin{array}{l}0.062 \\
(1.10)\end{array}$ & & $\begin{array}{l}-0.097 \\
(-1.25)\end{array}$ & & $\begin{array}{l}-1.915 \\
(-1.17)\end{array}$ & & $\begin{array}{l}0.064 \\
(0.42)\end{array}$ \\
\hline$M E A N \_Y$ & $\begin{array}{c}0.885 * * * \\
(3.65)\end{array}$ & $\begin{array}{c}0.879 * * * \\
(3.68)\end{array}$ & $\begin{array}{c}1.190 * * * \\
(7.42)\end{array}$ & $\begin{array}{c}1.191 * * * \\
(7.42)\end{array}$ & $\begin{array}{c}1.113 * * * \\
(3.98)\end{array}$ & $\begin{array}{c}1.118 * * * \\
(3.99)\end{array}$ & $\begin{array}{c}1.373 * * * \\
(4.04)\end{array}$ & $\begin{array}{c}1.369 * * * \\
(4.05)\end{array}$ & $\begin{array}{l}-0.025 \\
(-0.71)\end{array}$ & $\begin{array}{l}-0.025 \\
(-0.70)\end{array}$ & $\begin{array}{l}0.205 \\
(0.20)\end{array}$ & $\begin{array}{l}0.215 \\
(0.21)\end{array}$ \\
\hline constant & $\begin{array}{l}-0.505 \\
(-1.04)\end{array}$ & $\begin{array}{l}-0.473 \\
(-1.00)\end{array}$ & $\begin{array}{c}0.760 * * \\
(2.14)\end{array}$ & $\begin{array}{c}0.758^{* *} \\
(2.14)\end{array}$ & $\begin{array}{l}0.085 \\
(0.79)\end{array}$ & $\begin{array}{l}0.078 \\
(0.74)\end{array}$ & $\begin{array}{l}0.016 \\
(0.08)\end{array}$ & $\begin{array}{l}0.046 \\
(0.21)\end{array}$ & $\begin{array}{l}4.351 \\
(1.30)\end{array}$ & $\begin{array}{l}4.378 \\
(1.33)\end{array}$ & $\begin{array}{l}1.634 \\
(1.10)\end{array}$ & $\begin{array}{l}1.621 \\
(1.09)\end{array}$ \\
\hline $\mathrm{N}$ & 3,123 & 3,123 & 3,123 & 3,123 & 3,123 & 3,123 & 3,123 & 3,123 & 3,123 & 3,123 & 3,123 & 3,123 \\
\hline Adjusted R-squared & 0.125 & 0.126 & 0.180 & 0.180 & 0.091 & 0.092 & 0.157 & 0.155 & 0.006 & 0.006 & 0.123 & 0.123 \\
\hline
\end{tabular}


Table 9: Small BHCs versus very small BHCs. Parameters for equation (9), estimated for bank-year observations for U.S. BHCs between 1998 and 2012 with ASSETS less than \$1 billion. Alternate columns show results for BHCs above and below the median value of ASSETS. Models are estimated with fixed bank effects, fixed State effects, and fixed year effects, using ordinary least squares. The SHOCK variables are based on TIER12/RWA. BELOW is lagged two years. All other right-hand side variables are lagged one year.

\begin{tabular}{|c|c|c|c|c|c|c|c|c|c|}
\hline & \multicolumn{3}{|c|}{$\begin{array}{c}\text { ASSETS }<\$ 1 \text { billion } \\
\text { above-median observations }\end{array}$} & \multicolumn{3}{|c|}{$\begin{array}{c}\text { ASSETS }<\$ 1 \text { billion } \\
\text { below-median observations }\end{array}$} & \multicolumn{3}{|c|}{$\begin{array}{l}\text { ASSETS > } \$ 10 \text { billion } \\
\text { all observations }\end{array}$} \\
\hline BELOW & $\begin{array}{l}0.512 \\
(0.92)\end{array}$ & $\begin{array}{l}0.622 \\
(1.13)\end{array}$ & $\begin{array}{l}0.520 \\
(0.94)\end{array}$ & $\begin{array}{l}1.115^{*} \\
(1.96)\end{array}$ & $\begin{array}{c}1.273 * * \\
(2.30)\end{array}$ & $\begin{array}{l}1.100^{*} \\
(1.93)\end{array}$ & $\begin{array}{l}0.847 \\
(0.80)\end{array}$ & $\begin{array}{l}0.826 \\
(0.76)\end{array}$ & $\begin{array}{l}0.825 \\
(0.76)\end{array}$ \\
\hline SHOCK & $\begin{array}{l}0.553 * * \\
(2.27)\end{array}$ & & & $\begin{array}{l}0.674 * * \\
(2.35)\end{array}$ & & & $\begin{array}{l}0.192 \\
(0.36)\end{array}$ & & \\
\hline SHOCKSIZE & & $\begin{array}{l}0.235 \\
(1.29)\end{array}$ & & & $\begin{array}{l}0.208 \\
(0.96)\end{array}$ & & & $\begin{array}{l}0.215 \\
(0.46)\end{array}$ & \\
\hline $\operatorname{SHOCK}(0 \%-1 \%)$ & & & $\begin{array}{l}0.432 \\
(1.64)\end{array}$ & & & $\begin{array}{c}0.616^{* *} \\
(2.01)\end{array}$ & & & $\begin{array}{l}0.171 \\
(0.36)\end{array}$ \\
\hline $\operatorname{SHOCK}(1 \%-2 \%)$ & & & $\begin{array}{l}0.642 \\
(1.43)\end{array}$ & & & $\begin{array}{c}0.914^{*} \\
(1.94)\end{array}$ & & & $\begin{array}{l}0.413 \\
(0.38)\end{array}$ \\
\hline $\operatorname{SHOCK}(>2 \%)$ & & & $\begin{array}{l}0.776 \\
(1.12)\end{array}$ & & & $\begin{array}{l}0.675 \\
(0.87)\end{array}$ & & & $\begin{array}{l}0.260 \\
(0.21)\end{array}$ \\
\hline $\ln A S S E T S$ & $\begin{array}{c}-1.594^{*} \\
(-1.65)\end{array}$ & $\begin{array}{r}-1.604^{*} \\
(-1.66)\end{array}$ & $\begin{array}{c}-1.593^{*} \\
(-1.65)\end{array}$ & $\begin{array}{l}-2.228 \\
(-1.60)\end{array}$ & $\begin{array}{l}-2.100 \\
(-1.52)\end{array}$ & $\begin{array}{l}-2.246 \\
(-1.61)\end{array}$ & $\begin{array}{l}1.889 \\
(1.27)\end{array}$ & $\begin{array}{l}1.901 \\
(1.31)\end{array}$ & $\begin{array}{l}1.882 \\
(1.26)\end{array}$ \\
\hline LISTED & $\begin{array}{c}2.029 * * * \\
(2.98)\end{array}$ & $\begin{array}{c}2.001 * * * \\
(2.93)\end{array}$ & $\begin{array}{c}2.029 * * * \\
(2.97)\end{array}$ & $\begin{array}{c}3.518 * * * \\
(3.02)\end{array}$ & $\begin{array}{c}3.501 * * * \\
(3.03)\end{array}$ & $\begin{array}{c}3.508 * * * \\
(3.01)\end{array}$ & & & \\
\hline constant & $\begin{array}{c}24.204 * \\
(1.83)\end{array}$ & $\begin{array}{c}24.298^{*} \\
(1.85)\end{array}$ & $\begin{array}{c}24.173^{*} \\
(1.83)\end{array}$ & $\begin{array}{c}31.204^{*} \\
(1.73)\end{array}$ & $\begin{array}{c}29.470 \\
(1.64)\end{array}$ & $\begin{array}{c}31.443^{*} \\
(1.74)\end{array}$ & $\begin{array}{c}-30.743 \\
(-1.18)\end{array}$ & $\begin{array}{c}-30.961 \\
(-1.21)\end{array}$ & $\begin{array}{c}-30.618 \\
(-1.17)\end{array}$ \\
\hline $\mathrm{N}$ & 3,838 & 3,838 & 3,838 & 3,846 & 3,846 & 3,846 & 482 & 482 & 482 \\
\hline Adjusted R-squared & 0.192 & 0.191 & 0.192 & 0.130 & 0.129 & 0.130 & 0.194 & 0.194 & 0.191 \\
\hline
\end{tabular}


Table 10: High capital BHCs versus low capital BHCs. Parameters for equation (9), estimated for bank-year observations for U.S. BHCs between 1998 and 2012 with ASSETS less than \$1 billion. Alternate columns show results for BHCs above and below the median value of TIER12/RWA. Models are estimated with fixed bank effects, fixed State effects, and fixed year effects, using ordinary least squares. The SHOCK variables are based on TIER12/RWA. BELOW is lagged two years. All other right-hand side variables are lagged one year.

\begin{tabular}{|c|c|c|c|c|c|c|}
\hline & $\begin{array}{c}{[1]} \\
\text { TIERI2/RWA } \\
>\text { median }\end{array}$ & $\begin{array}{c}{[2]} \\
\text { TIERI2/RWA } \\
<\text { median }\end{array}$ & $\begin{array}{c}{[3]} \\
\text { TIER12/RWA } \\
>\text { median }\end{array}$ & $\begin{array}{c}{[4]} \\
\text { TIER12/RWA } \\
<\text { median }\end{array}$ & $\begin{array}{c}{[5]} \\
\text { TIER12/RWA } \\
>\text { median }\end{array}$ & $\begin{array}{c}{[6]} \\
T I E R 12 / R W A \\
<\text { median } \\
\end{array}$ \\
\hline$B E L O W$ & $\begin{array}{l}0.745 \\
(1.51)\end{array}$ & $\begin{array}{l}0.154 \\
(0.19)\end{array}$ & $\begin{array}{c}1.068 * * \\
(2.29)\end{array}$ & $\begin{array}{l}0.176 \\
(0.22)\end{array}$ & $\begin{array}{l}0.746 \\
(1.51)\end{array}$ & $\begin{array}{c}0.171 \\
(0.22)\end{array}$ \\
\hline SHOCK & $\begin{array}{c}1.017 * * * \\
(2.99)\end{array}$ & $\begin{array}{l}0.261 \\
(1.21)\end{array}$ & & & & \\
\hline SHOCKSIZE & & & $\begin{array}{l}0.219 \\
(1.01)\end{array}$ & $\begin{array}{l}0.212 \\
(1.06)\end{array}$ & & \\
\hline $\operatorname{SHOCK}(0 \%-1 \%)$ & & & & & $\begin{array}{c}0.806 * * \\
(2.19)\end{array}$ & $\begin{array}{l}0.164 \\
(0.75)\end{array}$ \\
\hline $\operatorname{SHOCK}(1 \%-2 \%)$ & & & & & $\begin{array}{c}1.743 * * * \\
(3.48)\end{array}$ & $\begin{array}{l}0.253 \\
(0.56)\end{array}$ \\
\hline $\operatorname{SHOCK}(>2 \%)$ & & & & & $\begin{array}{l}0.482 \\
(0.64)\end{array}$ & $\begin{array}{l}1.031 \\
(1.37)\end{array}$ \\
\hline $\ln A S S E T S$ & $\begin{array}{c}-3.253 * * \\
(-2.49)\end{array}$ & $\begin{array}{l}-0.394 \\
(-0.48)\end{array}$ & $\begin{array}{c}-3.148 * * \\
(-2.43)\end{array}$ & $\begin{array}{l}-0.372 \\
(-0.46)\end{array}$ & $\begin{array}{c}-3.277 * * \\
(-2.51)\end{array}$ & $\begin{array}{l}-0.366 \\
(-0.45)\end{array}$ \\
\hline LISTED & $\begin{array}{c}3.287 * * * \\
(2.84)\end{array}$ & $\begin{array}{c}1.960 * * \\
(2.51)\end{array}$ & $\begin{array}{c}3.186 * * * \\
(2.72)\end{array}$ & $\begin{array}{c}1.971 * * \\
(2.50)\end{array}$ & $\begin{array}{c}3.201 * * * \\
(2.75)\end{array}$ & $\begin{array}{c}1.984 * * \\
(2.52)\end{array}$ \\
\hline constant & $\begin{array}{c}45.449 * * * \\
(2.64)\end{array}$ & $\begin{array}{l}8.105 \\
(0.74)\end{array}$ & $\begin{array}{c}44.014 * * \\
(2.57)\end{array}$ & $\begin{array}{l}7.774 \\
(0.71)\end{array}$ & $\begin{array}{c}45.760 * * * \\
\quad(2.66)\end{array}$ & $\begin{array}{l}7.668 \\
(0.70)\end{array}$ \\
\hline $\mathrm{N}$ & 3,833 & 3,851 & 3,833 & 3,851 & 3,833 & 3,851 \\
\hline Adjusted R-squared & 0.159 & 0.171 & 0.156 & 0.171 & 0.159 & 0.171 \\
\hline
\end{tabular}


Figure 1

Mean annual NSFR, 1998-2012, by bank asset size (\$ billions)

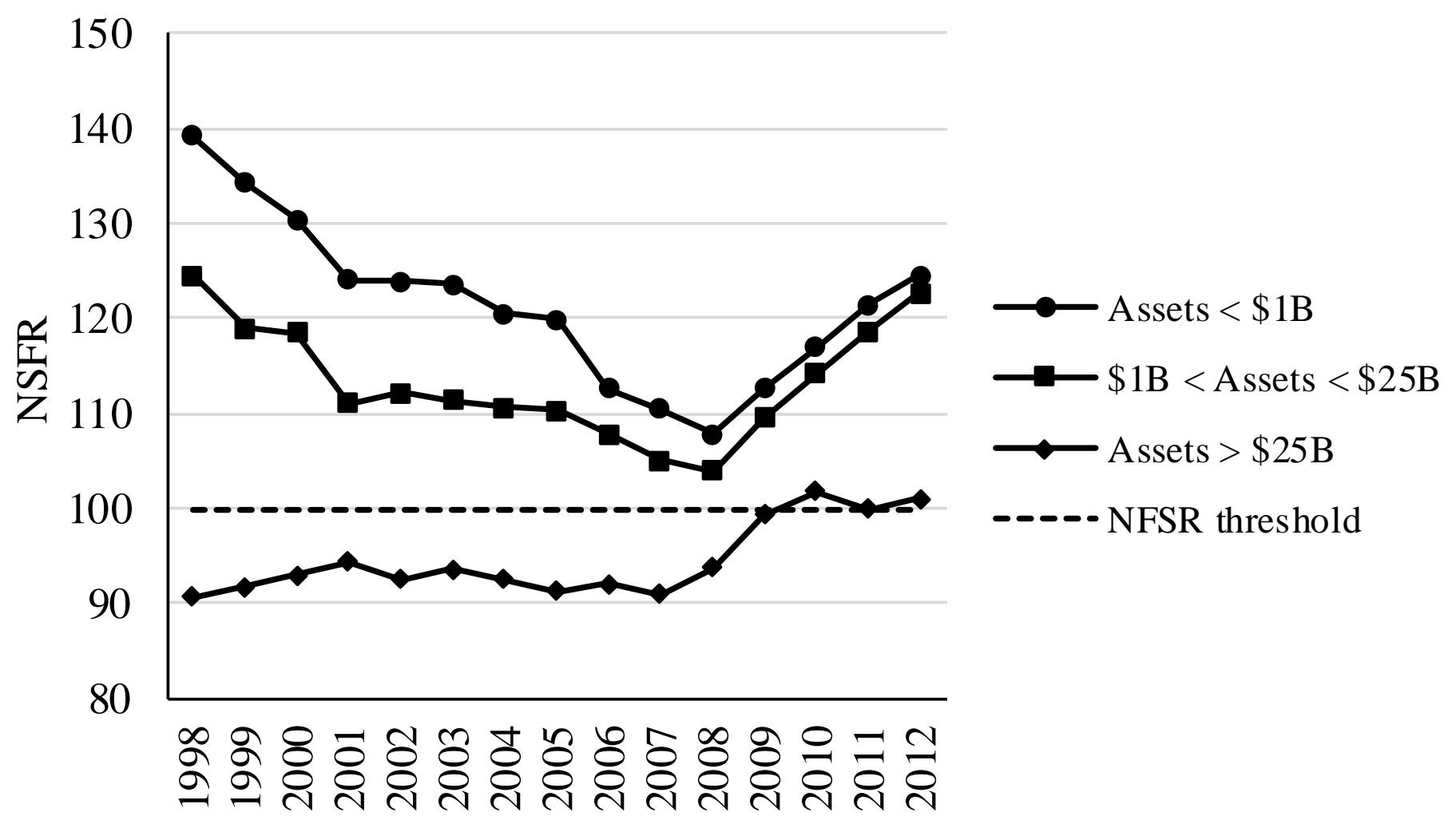


Figure 2

Timing in the empirical model

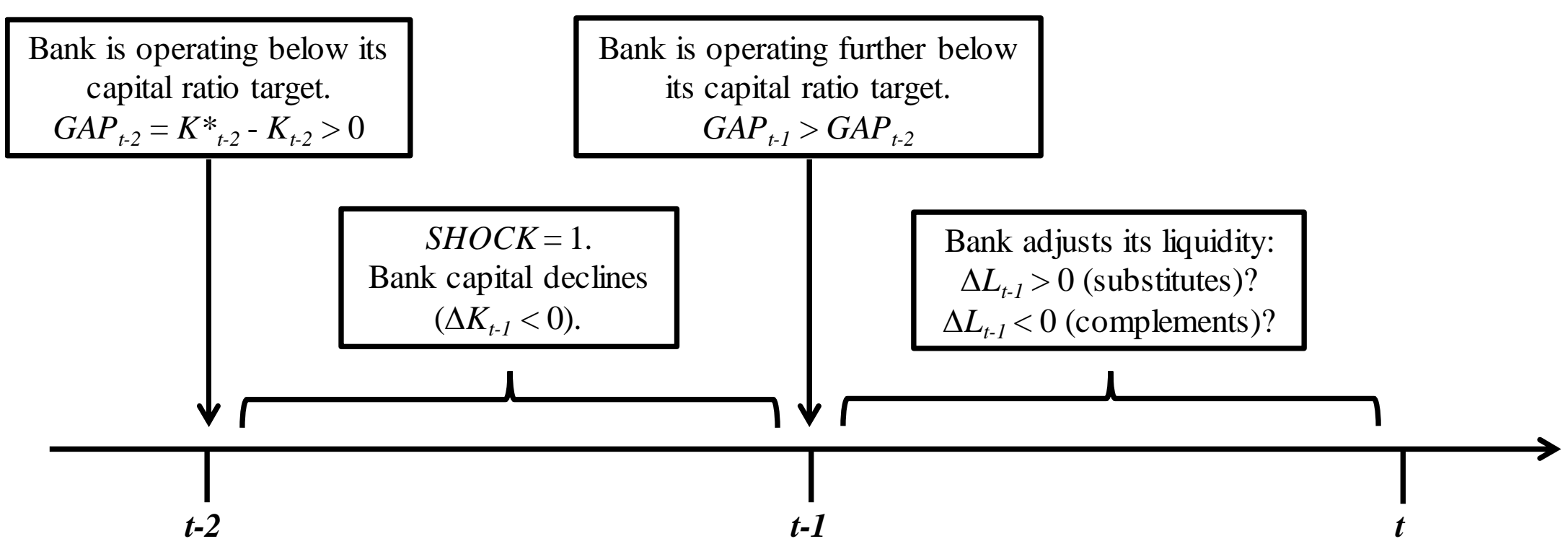

